\title{
DRONES, IMAGEM-TEMPO E O FIM DO PODER SOBERANO
}

\author{
Ulysses Pinheiro $^{1}$
}

Resumo: $\mathrm{O}$ artigo trata da especificidade de um dos produtos tecnológicos de vigilância e de ataque aéreos mais importantes em uso atualmente, os drones, mostrando em que sentido essa nova tecnologia traça um marco decisivo na evoluçāo do domínio dos ares e, portanto, como sugere Carl Schmitt, na transformação do campo teológico-político das sociedades contemporâneas. A imanência radical do campo político proposta pelo liberalismo, diagnosticada por Schmitt, terá nos drones um de seus instrumentos mais exemplares. Para caracterizar a especificidade dos drones frente a outros aparelhos visuais e aéreos de guerra, será proposta uma aproximação com o conceito de imagem-tempo de Gilles Deleuze, de tal modo a determinar essa sua singularidade a partir das propriedades intrínsecas da imagem gerada. A principal característica da imagem-tempo deleuziana a ser integrada à análise dos drones será seu aspecto tátil. Nesse momento, a aproximação dos livros de Deleuze sobre o cinema com sua obra escrita com Félix Guattari (especialmente $O$ anti-Édipo) será essencial para determinar a dimensão política da imagem-drone.

Palavras-Chave: Drones. Cinema. Guerra. Soberania.

\section{INTRODUÇÃo}

Segundo o diagnóstico que Carl Schmitt faz do liberalismo político, a ausência de transcendência que caracteriza sua forma estrutural não permite a instituição de um mecanismo de representação estatal forte o bastante para servir como mediador das relaçóes existentes no interior do corpo social. Neste artigo, mostraremos que os modernos instrumentos militares de vigilância e ataque, conhecidos popularmente como drones, realizam a última transformação do liberalismo em direção à imanência total dos meios de controle político. De fato, se, de acordo com Schmitt, o Estado moderno encontrou sua estabilidade graças ao domínio dos mares, a partir do século XVI, de sorte que o poder político passou a ser exercido não apenas no meio terrestre, mas também no

1 Departamento de Filosofia da Universidade Federal do Rio de Janeiro (UFRJ); bolsista de Produtividade em Pesquisa do CNPq. (ID) https://orcid.org/0000-0002-7687-1465 - E-mail: ulyssespinheiro@gmail.com

http://dx.doi.org/10.1590/0101-3173.2020.v43n1.12.p213

This is an open-access article distributed under the terms of the Creative Commons Attribution License. 
marítimo, o domínio aéreo posto em marcha no começo do século XX marca a derrocada final do Estado clássico em direção ao imanentismo liberal. A questão que teremos de responder diz respeito à especificidade dos drones, no contexto dessa última forma de dominação política; em particular, deveremos entender se há, em suas imagens, uma qualidade intrínseca que a distinga de outras formas de vigilância aérea. Veremos, então, que o conceito de imagemtempo, formulado por Gilles Deleuze em seus livros sobre o cinema, poderá determinar tal qualidade, de maneira a darmos uma resposta afirmativa à questão proposta.

\section{Drones e o olhar de Deus}

Em 1951, Salvador Dalí completou seu famoso quadro Cristo de São João da Cruz, o qual se encontra no Kelvingrove Museum, em Glasgow (Figura 1 abaixo).

Figura 1: Cristo de San Juan de la Cruz, de Salvador Dalí

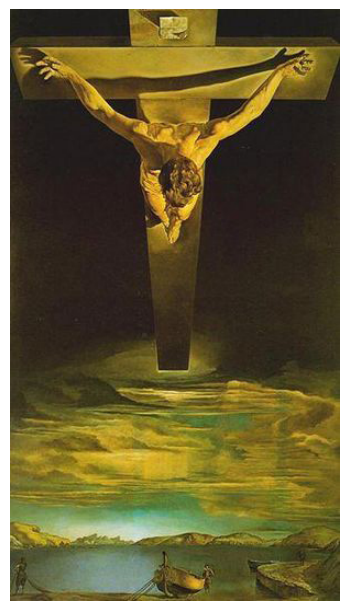

Disponível em: http://collections.glasgowmuseums.com/mwebcgi/mweb?request=record;id=1;type=101 Acesso em: 14 abr. 2017.

O título do quadro de Dalí exprime o reconhecimento de que a perspectiva peculiar a partir da qual é nele figurada a crucifixão de Jesus fora inspirada pelo desenho do místico carmelita do século XVI, São João da Cruz; 
esse último, por sua vez, imaginara sua obra (figura 2) em uma visão ocorrida durante suas preces ${ }^{2}$.

Figura 2: Cristo de San Juan de la Cruz

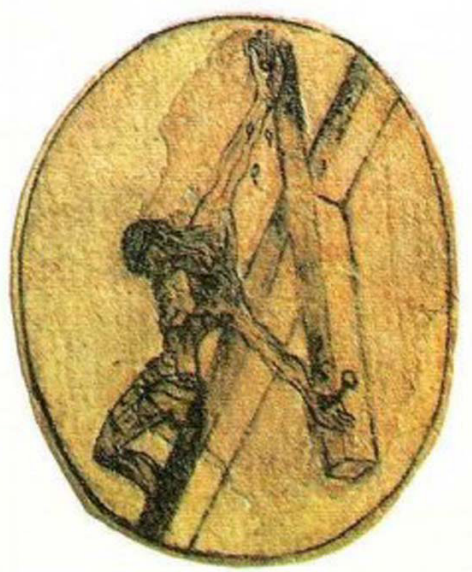

Disponível em: https://es.wikipedia.org/wiki/Vida_de_San_Juan_de_la_Cruz\#/media/ Archivo:CRISTO_SAN_JUAN.jpg Acesso em: 14 abr. 2017.

Ao contrário do desenho quinhentista, a pintura de Dalí omite a coroa de espinhos, os pregos e o sangue, elementos típicos da iconografia da crucifixão - pois, conforme o próprio autor, um "sonho cósmico" lhe revelara que eles mutilariam uma representação adequada do Cristo (DESCHARNES, 2003) (poderíamos supor, talvez, que essa instrução onírica ecoou inconscientemente as palavras de Santa Catarina de Sena, segundo a qual o Cristo é preso à cruz não por pregos, mas por amor). ${ }^{3}$ A novidade do quadro de Dalí não se limita, no entanto, à ausência desses elementos que associam a crucifixão ao sofrimento, instalando-a, ao contrário, em uma calma contemplativa na qual Jesus como que repousa serenamente sobre a cruz; além disso, outras diferenças relevantes com relação à obra de São João da Cruz devem ser notadas. Assim, enquanto o desenho desse último representa, para alguns, um pequeno crucifixo contemplado do ponto de vista de um moribundo, em sua última veneraçáo do símbolo sagrado, Dalí adota, de maneira inequívoca, o ponto de vista de Deus observando seu Filho, no momento da morte. O olhar do Cristo

2 O desenho encontra-se no Monasterio de la Encarnación de Ávila.

3 Seguimos aqui a sugestão de BROOKES (2011). 
crucificado, por sua vez, ao contrário do que ocorre no desenho do século $\mathrm{XVI}$, é ele mesmo um elemento importante do quadro, pois adivinhamos que ele mirava, ao morrer, um objeto determinado: flutuando no Ar, ele dirige-se à Terra e ao Mar, ao mundo habitado pelos homens, cuja presença é assinalada pelos pescadores e seu barco atracado à margem.

Como afirma recorrentemente Schmitt, a Terra, o Mar e o Ar articulam uma geografia política a partir da teologia. Uma das teses centrais da teologia política de Schmitt é, como se sabe, a de que "todos os conceitos significativos da moderna doutrina do Estado são conceitos teológicos secularizados" ": o poder soberano é, segundo as palavras de Schmitt, uma "meta-ana-catamorfose"s do domínio teológico, ou seja, ele surge quando ocorre uma transposição semântica (expressa pela raiz grega " $\mu \varepsilon \tau \alpha$ "), a qual, simultaneamente, é também uma

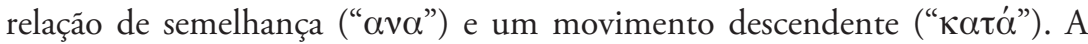
instauração do campo político é, assim, de acordo com Schmitt, um cataclismo ou uma catástrofe, na medida em que a teologia tem preeminência sobre o político e o legitima: o Estado passa a ocupar, de maneira subalterna, o lugar transcendente do Deus monoteísta. O caráter catamórfico da instauração do Estado explica-se a partir da perspectiva do catolicismo de Schmitt: contra o relativismo subjetivista dos liberais, adeptos de uma teologia da imanência e da imediação, ele opóe - de modo apenas aparentemente paradoxal - uma outra imediação, aquela presente na decisão fundadora do domínio estatal, isto é, fundadora do dominio das mediaçóes. Ou ainda: contra a anomia liberal, apenas um ato decisório imediato pode estabelecer a mediação política capaz de instanciar os valores presentes na forma institucional da Igreja católica. ${ }^{6}$

4 "Alle prägnanten Begriffe der modernen Staatslehre sind säkularisierte theologische Begriffe." SCHMITT (2004, p. 43).

5 Cf. SCHMITT (1970, p. 58). Nesse trecho, Schmitt propóe uma reciprocidade total entre os domínios teológico e político, o que pareceria contrariar a interpretação que ofereço a seguir para a catamorfose, na qual haveria uma assimetria essencial entre os dois domínios. De fato, reproduzindo nesse ponto parte do vocabulário de Ernest Topitsch, Schmitt refere-se a um jogo de espelhos [Spiegelung und Rückspiegelungen] que oporia simetricamente o teológico e o político. Creio, no entanto, como procuro mostrar na sequência do texto, que o isomorfismo aí tematizado é compatível com a tese de uma assimetria essencial entre os dois âmbitos, com vantagem para a eminência da teologia.

6 Sigo aqui a interpretação de Franco de Sá (2009). Ainda assim, seria preciso introduzir algumas nuances na interpretaçáo adotada. De fato, embora a obra de Schmitt seja caracterizada por um decisionismo marcante desde o período de Weimar, com Teologia política II, na década de 1970, fica claro que tal decisionismo não se confunde com o domínio do puramente arbitrário, já que o critério de escolha é a forma da ordem, contra a anomia liberal. Quer dizer, é a forma institucional da Igreja que dá o modelo da forma estatal e do poder soberano. Sobre isso, deve-se consultar sua obra de 1923, Römischer Katholizismus und politische Form. 
É esse modelo teológico-político que constitui, ainda segundo Schmitt, a base de nossa adesão à forma estatal. ${ }^{7}$ Já alguns anos depois da Segunda Guerra Mundial, Schmitt volta a escrever sobre o Estado nacional, mas dessa vez em um tom mais pessimista, tematizando seu fim; em $O$ nomos $d a$ Terra no direito das gentes do jus publicum europaum, ele expóe como o direito nasce da tomada e da partilha da terra: é a partir desse ato político fundamental e injustificado que o sistema jurídico e, consequentemente, o poder soberano, são constituídos. $\mathrm{O}$ nomos da Terra, efetivado a partir da época das grandes descobertas do século XVI, escreve Schmitt, "reside em uma determinada relação entre terra firme e mar livre" ${ }^{\text {; }}$ contudo, é só no século XVII, com o fim da Guerra dos Trinta Anos e a assinatura do Tratado de Vestfália, que o direito internacional moderno garantiu aos países europeus uma certa estabilidade e previsibilidade em suas relaçóes mútuas, o que permitiu o surgimento do poder soberano instalado nos Estados nacionais. Na verdade, é apenas a partir dessa época que há propriamente um nomos da Terra, pois é ao longo dos Descobrimentos, no século XVI, que se forma uma imagem global do planeta e se inicia uma batalha pelo domínio dos mares. Entretanto, com o fim da Primeira Guerra Mundial, adverte-nos Schmitt (2014, p. 64),

[...] graças a um novo acontecimento espacial, a possibilidade de um domínio do espaço aéreo, ambos - terra firme e mar livre - transformaramse drasticamente, tanto em si mesmos como em suas relaçóes recíprocas. [...] Começa, assim, uma nova etapa da consciência humana do espaço e da ordem globais.

Aceitando essa premissa de Schmitt, podemos nos perguntar quais são as qualidades, que tipo de catamorfose teológica e de catástrofe militar (notemos que agora o radical " $\kappa \alpha \tau \alpha$ ” assume um sentido literal, o de domínio exercido a partir de cima, a saber, dos céus) a disputa pelo domínio aéreo impóe às práticas políticas contemporâneas. Mais particularmente, interessa-nos aqui entender a especificidade de um dos produtos tecnológicos de vigilância e de

\footnotetext{
${ }^{7}$ Que essa decisão fundamental pela forma estatal seja a única modalidade de racionalidade possível diante do imanentismo moderno náo elimina inteiramente a circunstância de que, na base dessa alternativa ao liberalismo político, encontramos uma espécie peculiar de pensamento mítico, baseado na manifestaçấo visível de Deus em sua Igreja - ou seja, de um pensamento que muitos liberais não hesitariam em denominar "irracional".

${ }^{8}$ SCHMITT (2014, p. 46). Sobre a preferência de Schmitt pelo termo grego nomos ao termo "lei" (Gesetz), cf. p. 65-71; segundo Schmitt, tal preferência se deve ao fato de a primeira conter em seu significado a ideia de localização - "O nomos é, portanto, a forma imediata na qual a ordem política e social de um povo se torna espacialmente visível.” (p. 69).
} 
ataque aéreos mais importantes em uso atualmente, os drones, devido a algo que, por ora, não pode se enunciar senáo sob a forma de uma suspeita: a de que essa nova tecnologia traça um marco decisivo na evolução do domínio dos ares (deixemos em suspenso se tal limite indica o começo de uma nova forma de dominação ou apenas a realização plena de um processo já em curso há muitas décadas).

\section{A SEMELHANÇA ENTRE DRONES E OUTROS INSTRUMENTOS AÉREOS DE DOMINAÇÃo}

É difícil determinar a quantidade de drones militares existentes hoje, pois esses dados são, em grande parte, sigilosos - por exemplo, não se tem praticamente nenhuma informaçáo sobre os aparelhos da Rússia, da China e da Turquia. Calcula-se que há mais de 56 tipos de drones militares em atividade, monitorando, pelo menos, 11 países - como era de se esperar, os Estados Unidos provavelmente lideram o número de drones e, certamente, o número de ataques, realizados, em sua maioria, no Afeganistão, no Paquistão, no Iêmen e na Somália. ${ }^{9}$ Em 2014, por exemplo, o governo americano operou pelo menos entre 8.000 e 9.000 drones militares de tamanho médio e grande ${ }^{10}$ (uma curiosidade doméstica: o Brasil importa drones de Israel). ${ }^{11}$

Analisado do ponto de vista de categorias teológico-políticas, é possível afirmar que o drone emula o olhar de Deus - ele é uma máquina-olho que, como observou Virilio (1989, p. 4),

[...] em uma versão técnica da Divindade onividente, excluindo permanentemente o acidente e a surpresa, [tem como objetivo] a construçáo de um sistema geral de iluminação que permitirá que tudo seja visto e conhecido, em cada momento e em cada lugar.

\footnotetext{
${ }^{9}$ Cf. Drones Wars: The Full Data. The Bureau of Investigative Journalism. 2017. Disponível em: https:// www.thebureauinvestigates.com/stories/2017-01-01/drone-wars-the-full-data. Acesso em: 14 abr. 2017.

${ }^{10}$ Pentagon Plans for Cuts to Drone Budgets. 2014. Disponível em: https://www.dodbuzz. com/2014/01/02/pentagon-plans-for-cuts-to-drone-budgets/. Acesso em: 14 abr. 2017.

11 Israel já tenta controlar tecnologia militar brasileira. Outras Mídias. 29 ago. 2016. Disponível em: http://outraspalavras.net/outrasmidias/destaque-outras-midias/como-israel-quer-controlar-tecnologiamilitar-brasileira/. Acesso em: 24 abr. 2017. Para uma visão sinóptica sobre a posse e uso dos drones militares, cf. How We Became a World of Drones. World of Drones. Disponível em: https://www. newamerica.org/in-depth/world-of-drones/. Acesso em: 14 abr. 2017.
} 
O enquadramento congelado de um vídeo que vemos abaixo (figura 3) registra uma das milhares de imagens produzidas diariamente - no caso, filmada por um drone atacando um comboio iraquiano perto de Mosul:

Figura 3: Pinpoint ISIS drone strike obliterates Iraqi Army humvee near Mosul. Al Masdar News

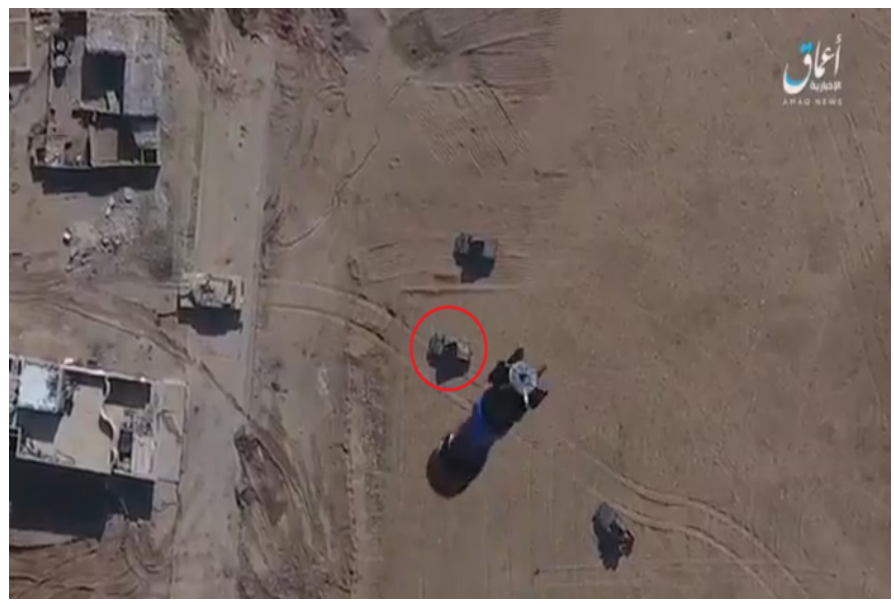

Disponível em: https://www.almasdarnews.com/article/video-pinpoint-isis-drone-strike-obliteratesiraqi-army-humvee-near-mosul/

Acesso em: 22 abr. 2017.

Tal como o olho de Deus no quadro de Dalí, a cena vislumbrada pelo drone é a dupla apresentação da morte e do território - mas ela está mais próxima da divindade do Antigo Testamento, que, tomando a forma de uma nuvem, flutuou sobre o povo eleito durante 40 anos na travessia do deserto, encarregada que era de vigiar e punir, do que da perspectiva do Deus-Pai contemplando a morte de seu Filho. (Mas não devemos nos esquecer de que o Deus do Antigo Testamento é, ao menos em certo sentido, o mesmo Deus do Novo Testamento, e que o olhar do Pai sobre seu Filho morto no quadro de Dalí indica, na sua distinção em relação ao olhar moribundo de Jesus, tal identidade fundamental que perpassa os dois Testamentos - há, pois, uma ameaça que impregna esse olhar compassivo do Pai, como a calmaria antes da tempestade, já antevendo o dia do Juízo Final). O Deus terrível do Antigo Testamento intervinha frequentemente no mundo sublunar, e, para voltar à catamorfose teológico-política, não devemos nos esquecer de que, além da visão, há uma dimensão tátil na tecnologia dos veículos aéreos não-tripulados: 
tal como uma prótese do poder soberano, os drones militares podem tocar e destruir os inimigos do Estado. ${ }^{12}$

No entanto, até que ponto o projeto de visibilidade total efetivado na tecnologia dos drones anuncia uma novidade, do ponto de vista político? Muito se tem dito sobre a nova configuração que os drones trazem para a definiçãa mesma de guerra, na medida em que eles reduzem a zero o risco de vida das pessoas engajadas nas forças de ataque - de fato, sendo controlados a milhares de quilômetros de distância, os militares que operam os drones em bases aéreas nos Estados Unidos, por exemplo, podem terminar seu dia de combate, eventualmente coroado por dezenas de mortes, buscando seus filhos no colégio ou fazendo compras no supermercado a caminho de casa.

Como não examinaremos aqui os aspectos éticos da assim chamada "guerra limpa" (para uma tal abordagem, pode-se consultar o livro recente de Grégoire Chamayou, intitulado $A$ Theory of the Drone, especialmente o capítulo "Necroética"13), a questão formulada acima deve ser entendida como tendo sido motivada sobretudo pela já mencionada suspeita quanto à real novidade dos drones, em sua dimensão geopolítica. Sob esse aspecto, não é inteiramente óbvio que estejamos vivendo em um contexto qualitativamente diferente do que já se desenhava (aceitando novamente a cronologia de Schmitt) desde a Primeira Guerra Mundial, identificando nela o fim da concepção europeia de soberania. Nesse sentido, deve-se notar que veículos aéreos não-tripulados foram extensivamente usados já desde a guerra de 1914: estereoscópios em aviốes capturavam os movimentos dos inimigos em fotos, as quais eram posteriormente coladas conjuntamente para formar grandes mapas-mosaicos do teatro de guerra. Em uma só batalha em 1916, por exemplo, a Real Força Aérea britânica imprimiu cerca de 430.000 fotografias desse tipo. ${ }^{14} \mathrm{Um}$ exemplo de mapa-mosaico pode ser visto abaixo (figura 4$)^{15}$ :

${ }^{12}$ Sobre uma análise dos drones como "próteses" e como "objetos metafísicos", cf. Benjamin Noys, Drone Metaphysics (2015).

${ }^{13}$ CHAMAYOU (2015, p. 127): "Se há alguma coisa nova nessa situação, ela poderia residir no fato de que a invulnerabilidade quase perfeita, em termos práticos, do lado dominante era, no final do século XX, estabelecida como a norma ética e política dominante."

${ }^{14}$ SHAW, Ian G. R. The Rise of the Predator Empire: Tracing the History of U.S. Drones. Understanding Empire, 2014. Disponível em: https://understandingempire.wordpress.com/2-0-a-brief-history-of-us-drones/. Acesso em: 14 abr. 2017.

${ }^{15}$ (Air photograph No 5906. Sheet 51B N18 etc. Guemappe, Cherisy etc) (C) IWM (Q 17254). 
Figura 4: Mosaic of aerial photographs of the trenches taken during the First World War

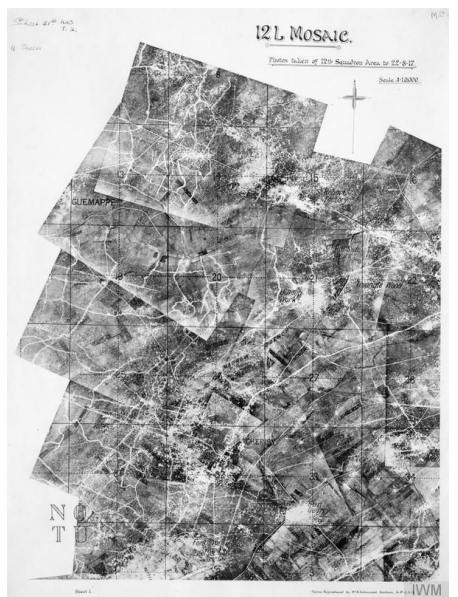

Disponível em: http://www.mylearning.org/first-world-war-aviation/images/2-4774/ Acesso em: 22 abr. 2017.

Que os drones não instaurem uma ruptura qualitativa com relação ao que já vinha sendo feito há muito tempo pode se tornar ainda mais plausível, quando se considera que, afinal de contas, o objetivo de conseguir o máximo alcance de ataque à maior distância possível do alvo sempre foi o desafio da balística - o poder soberano, mesmo na época em que o nomos da Terra não se articulava nem ao menos sob a forma de domínio dos mares, e muito menos do ar, mas se restringia às civilizaçôes puramente terrestres, buscava esse tipo de prótese de seus braços e mãos, avançando sobre o território inimigo, desde a invenção de tecnologias como o arco-e-flecha e a catapulta. Quando nos deslocamos para o período de disputa pelo domínio do ar, o uso de balóes, de aviōes e de helicópteros já associava a produção de imagens à execução de ataques aéreos muito antes dos atuais drones; além disso, os satélites gravitando na órbita da Terra se encarregavam, desde a Guerra Fria entre Estados Unidos e União Soviética, da produção de imagens em tempo real do território inimigo (a partir da assinatura do Tratado sobre o uso do espaço, em 1967, boa parte dos países se comprometeu a náo usar satélites como portadores de armas de destruição em massa ${ }^{16}$, embora seja difícil comprovar o real

${ }^{16}$ Cf. o Treaty on Principles Governing the Activities of States in the Exploration and Use of Outer Space, including the Moon and Other Celestial Bodies. In: United Nations Office for Disarmament Affairs. Disponível em: http://disarmament.un.org/treaties/t/outer_space. Acesso em: 22 abr. 2017. 
cumprimento do que foi entáo acordado). ${ }^{17}$ Ao que tudo indica, portanto, os drones apresentam apenas uma diferença de grau, e não de natureza, com relação a essas tecnologias aéreas desenvolvidas a partir do final do século XIX. Se for assim, então, o tipo de modelo teológico associado a essa emulação do olhar divino já estaria em operação há mais de um século.

Poder-se-ia objetar que a distância intermediária ocupada pelos drones, entre os balóes e helicópteros, por um lado, e os satélites espiôes, por outro, introduziria, por si só, uma qualidade nova ao domínio dos ares, na medida em que o deslocamento do olhar do soberano para o interior do território inimigo viria acompanhado de uma possibilidade ausente nas tecnologias anteriores, a saber: a de alternar imagens estáticas e imagens em movimento (tanto movimento horizontal quanto vertical), sem o incômodo da estridente visibilidade dos helicópteros. Ou seja, por mais que estejam sujeitos à detecção por radares, seu tamanho relativamente pequeno, somado a sua velocidade e navegabilidade, asseguraria aos drones uma invisibilidade relativa; a distância intermediária que eles ocupam entre os satélites e os helicópteros, por sua vez, lhes daria a proximidade com os assuntos terrenos que se espera de uma divindade onisciente, dotada da liberdade de deter seu olhar neste ou naquele detalhe humano, ao contrário do que ocorria no caso dos aviôes. Além disso, a possibilidade de unir a visão em tempo real com a decisão imediata de ataque daria aos drones a propriedade propriamente divina de conjugar em si o ver e o fazer, a contemplação e a intervenção. Se os drones passarem a ser autônomos, dotados de inteligência artificial ${ }^{18}$ - e já estão em teste hoje enxames de microdrones, capazes de tomar decisóes coletivas, como um enxame -, tal propriedade se tornaria ainda mais evidente, pois lidaríamos quase que literalmente com um deus ex machina inumano e transcendente, não só ao território, mas às próprias avaliaçóes políticas dos homens relativas à decisão de atacar ou não um determinado alvo.

Entretanto, essa objeção ainda náo elimina a suspeita de que, em todos esses casos, estaríamos lidando apenas com diferenças de graus entre tecnologias da visão aérea, e não com diferenças qualitativas. Se Virilio tem razão, o poder se exerce hoje menos em razão de um controle do espaço do que

\footnotetext{
${ }^{17}$ Cf. a reportagem de David Axe, publicada em 10 de agosto de 2015: When it comes to war in space, U.S. has the edge. Reuters. Disponível em: http://blogs.reuters.com/great-debate/2015/08/09/the-u-smilitary-is-preparing-for-the-real-star-wars/. Acesso em: 22 abr. 2017.

${ }^{18}$ New generation of drones set to revolutionize warfare, de David Martin. 60 Minutes. Disponível em: http://www.cbsnews.com/news/60-minutes-autonomous-drones-set-to-revolutionize-militarytechnology/; Artificial intelligence and drones "future of policing", de Gemma Ryall. BBC News. Disponível em: http://www.bbc.com/news/uk-wales-south-east-wales-39529504. Acesso em: 16 abr. 2017.
} 
do tempo; ora, sendo a velocidade aquilo que admite graus, toda a tecnologia contemporânea de vigilância e de combate seria apenas uma forma cada vez mais eficaz de administrar o intervalo entre observador e objeto, decisão e ação. Portanto, de uma perspectiva que poderíamos chamar de "epistêmica", seria talvez mais prudente supor que a era do domínio do ar tenha permanecido inalterada pelo menos desde o começo do século XX. Mas isso não nos impede de tentar explorar algumas especificidades ligadas ao uso dos drones, as quais, sem constituir uma ruptura com esse paradigma, lhe conferem uma particular aceleração - e se, em alguns casos ao menos, diferenças quantitativas acabam engendrando diferenças qualitativas, talvez, por outro lado, pudéssemos até mesmo concluir que a era dos drones representa de fato uma nova realidade política ou, pelo menos, realiza a completude da metamorfose em curso desde o fim do nomos da Terra europeu. Para tanto, ao invés de centrar a análise sobre a dimensão maquínica dos drones, manifesta em seu design específico, em sua capacidade de voo ou em seu potencial balístico, todas elas características que remetem mais facilmente a discussões éticas sobre a "guerra limpa", façamos um esforço prévio de tentar descobrir, nos próprios signos visuais produzidos por eles, considerados em si mesmos, tais especificidades.

Antes de prosseguir nessa direção, no entanto, é preciso fazer uma última ressalva, a saber: boa parte do que pode ser dito sobre as imagens capturadas por drones aplica-se igualmente às imagens feitas por satélites, por oposição às imagens obtidas a partir de avióes, helicópteros ou balóes. Isso fica claro quando consideramos o uso não-militar (o que não significa, obviamente, não-político) dos satélites e drones empregados para delimitação de territórios ou para fins comerciais, tal como para a agricultura, nos quais a questão sobre as vantagens e desvantagens de cada uma das tecnologias ainda é muitas vezes debatida. ${ }^{19}$ A maior amplitude de visão e a maior facilidade logística para a obtenção de imagens - independentemente de questôes relativas, por exemplo, à invasão do espaço aéreo de outras nações -, características dos satélites, são muitas

\footnotetext{
${ }^{19}$ Ver, por exemplo, a página na Internet da firma Landpoint, dedicada à engenharia de óleo e gás, na qual ela procura esclarecer seus clientes sobre os prós e contras das duas tecnologias: Satellite Versus UAV Mapping: How Are They Different? Disponível em: http://www.landpoint.net/satellite-versus-uavmapping-how-are-they-different/. Acesso em: 22 abr. 2017.

Ver também o artigo Intercomparison of UAV, Aircraft and Satellite Remote Sensing Platforms for Precision Viticulture, de Alessandro Matese et al. Remote Sensing, Suiça, v. 7, p. 2971-2990, 2015.

Também é significativo constatar que já se pensa em substituir os satélites por drones capazes de voar em altitude elevada por longos períodos, alimentados por energia solar; sobre esse ponto, cf. Airbus Wants to Replace Satellites With High-Flying Drones. Wired. Disponível em: https://www.wired.com/2016/06/ airbus-new-drones-actually-high-flying-pseudo-satellites/. Acesso em: 22 abr. 2017.
} 
vezes compensadas pela maior qualidade das imagens feitas pelos drones, os quais operam a uma distância muito menor do solo; a diferença entre ambos, entretanto, não é inteiramente clara, pelo menos no que diz respeito apenas à captura de imagens. Tanto os satélites quanto os drones permitem a vigilância em tempo real; ambos também possibilitam que imagens em movimento sejam focalizadas a distâncias variadas, a partir de um ponto de vista fixo.

Os drones são, certamente, mais úteis no nível da inteligência tática, enquanto os satélites ensejam uma visão ampla do território e, por isso, facilitam a percepção de mudanças estratégicas de larga escala ocorridas ao longo de um maior período tempo. Se, ainda assim, for possível estabelecer uma distinção significativa entre as imagens produzidas por drones e por satélites, será preciso incorporar às imagens dos primeiros uma qualidade qualquer ausente das imagens obtidas pelos últimos. Adiantemos desde já que procuraremos tal diferença qualitativa em uma dimensão háptica característica das imagens feitas pelos drones. Aqui é preciso atenção: não se trata apenas de acoplar, à produção de imagens por drones, sua capacidade "tátil" de atingir os inimigos através de seu poder de fogo, mas antes de encontrar, no interior mesmo das imagens, uma dimensão tátil. ${ }^{20}$ Voltaremos a esse ponto mais adiante.

\section{A ESPECIFICIDADE DOS DRONES}

Por ora, devemos investigar os signos visuais produzidos pelos drones, para buscar neles sua possível especificidade. A distinção, proposta por Deleuze, em seus dois livros sobre cinema, entre imagem-movimento e imagem-tempo será o ponto de partida de tal investigação. Antes de prosseguir, porém, é importante propor um novo adiamento, desta vez para que uma observaçáo metodológica seja claramente enunciada: como é bem sabido por aqueles que já folhearam esses dois livros de Deleuze, um de seus pressupostos iniciais é o de que a leitura de filmes por ele proposta se opóe firmemente a todas as tentativas da hermenêutica de tomar as imagens como o aspecto fenomênico de uma narrativa subjacente. Contra tal procedimento, Deleuze (1990a, p. 39) afirma que "[...] a narração não passa de uma consequência das próprias imagens aparentes e de suas combinaçôes diretas." Examinar as "imagens aparentes", no entanto, não significa descartar a dimensão semântica dos signos, em nome de uma análise puramente formalista, sintática, do cinema; a estratégia deleuziana consiste, ao invés disso, em tomar a forma dos signos

${ }^{20}$ É possível adiantar desde já que será preciso levar em conta, para realizar essa assimilação do háptico ao visual, recorrer às análises de Jacques Derrida, em seu livro Memórias de cego. 
visuais como seu conteúdo - o meio é a mensagem, como já dizia Marshall McLuhan -, de modo a traçar uma lógica ${ }^{21}$ própria das imagens, sem a suposição de que elas instanciem uma narrativa. As imagens, em suma, para Deleuze (1990b), não formam uma linguagem.

Feita essa advertência metodológica, lembremos brevemente em que consiste, segundo Deleuze, a distinção entre imagem-movimento e imagemtempo. ${ }^{22} \mathrm{~A}$ imagem-movimento é, para ele, a que caracteriza a primeira etapa da história do cinema, aquela que termina ao final da Segunda Guerra Mundial, na qual não só eram registrados movimentos no interior de um quadro estático (o que era o procedimento do cinema primitivo, como o dos irmãos Lumière e seu trem chegando à estação), mas onde o próprio enquadramento se movia e formava um todo orgânico através da montagem. Na imagemmovimento, tratava-se de integrar os signos visuais a respostas virtuais do esquema sensório-motor da plateia, sem que, porém, as imagens resultantes se limitassem simplesmente a emular o olho demasiadamente humano dos espectadores. Poderíamos generalizar para toda imagem-movimento aquilo que Deleuze (1990a, p. 44) diz de Dziga Vertov:

Em Vertov, o intervalo de movimento é a percepção, o olhar de relance, o olho. Simplesmente, o olho não é o olho demasiado imóvel do homem, é o olho da câmera, isto é, um olho na matéria, uma percepção tal como existe na matéria [....] A correlaçáo entre uma matéria náo humana e um olho sobre-humano é a própria dialética, pois é, principalmente, a identidade de uma comunidade da matéria com um comunismo do homem.

Ou, como afirmou o próprio Vertov (1972, p. 126-127, apud DELEUZE (1990a, p. 106), o cine-olho é o que “[...] engancha qualquer ponto do universo a outro em qualquer ordem temporal.” A imagem-movimento é, por isso, uma imagem indireta do tempo: diretamente, ela faz variar os movimentos relativos de um objeto, pois o próprio enquadramento se move e se reparte, quando o objeto se move em seu interior e as diferentes cenas são conectadas através da montagem ${ }^{23}$, mas o tempo é figurado apenas em relação ao todo da montagem,

\footnotetext{
${ }^{21}$ Deleuze evita o uso da palavra "semiologia" para caracterizar seu projeto, pois essa ciência dos signos opera no nível dos códigos e das semelhanças. Cf. DELEUZE (1990a, p. 40).

${ }^{22}$ Para uma análise mais aprofundada dessa distinção, ver BOGUE (2003, p. 107-111).

${ }^{23}$ Como nota François Zourabichvili, há uma certa ambiguidade no uso que Deleuze faz da expressão "imagem-movimento", na medida em que ela é algumas vezes identificada com as tomadas (shots) e, em outras ocasiōes, com a montagem, isto é, com um conjunto (ensemble) de tomadas, reagindo umas sobre as outras. Contudo, essa ambiguidade não chega a ser uma contradição, segundo o autor, pois a imagemmovimento, tomada em si mesma, contém esse duplo aspecto: "A imagem cinemática pode, de fato, parece ser distinta dos movimentos que ela mostra, um puro enquadramento, uma imagem do movimento. Mas
} 
um todo ele mesmo movente - movente no tempo - pois, a cada novo elemento, ele se reconfigura inteiramente (para usar um vocabulário clássico, não se trata de um totum analítico, mas de um totum sintético). Podemos ver abaixo (figura 5) um fotograma do famoso filme $O$ homem com uma câmera, de Vertov, de 1929, coordenando justamente a visão aérea do espaço à máquina-olho:

Figura 5: Chelovek s kino-apparatom, de Dziga Vertov

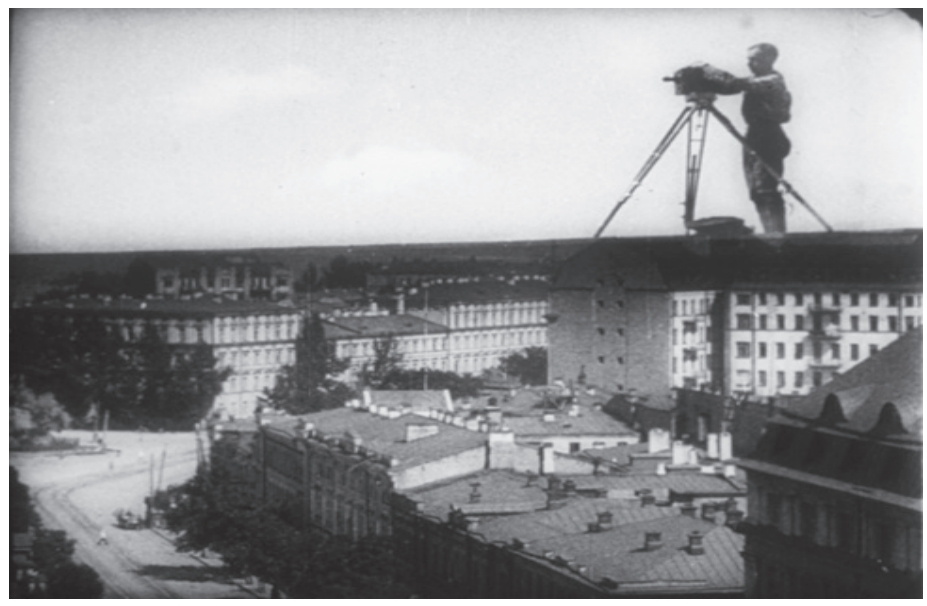

Disponível em: https://pt.wikipedia.org/wiki/Ficheiro:Man_with_a_movie_camera_1929_3.png

Acesso em: 22 abr. 2017.

Em contraste com a imagem-movimento, a imagem-tempo é, segundo a taxonomia deleuziana, inventada a partir do cinema do pós-guerra (embora tenha sido antecipada por alguns, como Yasujiro Ozu, no Japão) e envolve uma imagem direta do tempo dada pelas relaçóes não-localizáveis das situaçóes óticas e sonoras puras, opsignos e sonsignos relacionados pelos falsos raccords. ${ }^{24}$ Do mesmo modo como o conceito de história em Hegel, segundo o qual a segunda

o que a torna, de direito, uma imagem-movimento é que ela pode ser reunida ('montéé). Se Deleuze vê na montagem (muito mais do que na câmera movente) a assinatura mesma do cinema, é porque a montagem provoca uma mudança completa na perspectiva: a imagem não está mais apenas em sintonia com coisas moventes, ela extrai e autonomiza o movimento dessas coisas, de modo a conectá-los a outros movimentos, quer seja das mesmas coisas ou de coisas diferentes. Daí o caráter duplo da tomada: como uma imagem enquadrada, ela contém os movimentos entre as diferentes partes de um conjunto; como uma imagem reunida ('montéé), ela se funde com esses movimentos, os quais se tornam válidos por si mesmos, separados de seu suporte mundano ('A tomada é movimento').” (ZOURABICHVILI (2000), p. 143-144).

${ }^{24}$ DELEUZE (1990b, p. 55): "Os falsos raccords sâo a própria relaçấo nẫo-localizável: as personagens não os saltam mais, mas mergulham neles. Para onde foi Gertrude? Para os falsos raccords...” 
ocorrência de um fato histórico (sua repetição) instaura a primeira ocorrência (o que é repetido), assim também, na história do cinema de Deleuze, foi preciso o surgimento do cinema moderno para "reler todo o cinema [clássico] como já feito de movimentos aberrantes": "A imagem-tempo direta é o fantasma que sempre assombrou o cinema, mas foi preciso o cinema moderno para dar corpo a esse fantasma. Essa imagem é virtual, diferentemente da atualidade da imagem-movimento.” DELEUZE (1990b, p. 56).

Virtualidade distingue-se de atualidade, assim como a presença do passado puro na memória se distingue do tempo medido pelo deslocamento de corpos - os ecos bergsonianos de Deleuze são aqui patentes. O resultado é que a própria noção de montagem se modifica: porque opera com imagens diretas do tempo, a montagem as sintetiza, de sorte a produzir os já mencionados "movimentos aberrantes." (DELEUZE, 1990b). Podemos ver abaixo (figura 6) um fotograma do filme A Noite, de Michelangelo Antonioni, de 1961, também figurando uma tomada aérea, filme esse que ilustra perfeitamente a montagem moderna ${ }^{25}$ :

Figura 6: La notte, de Michelangelo Antonioni

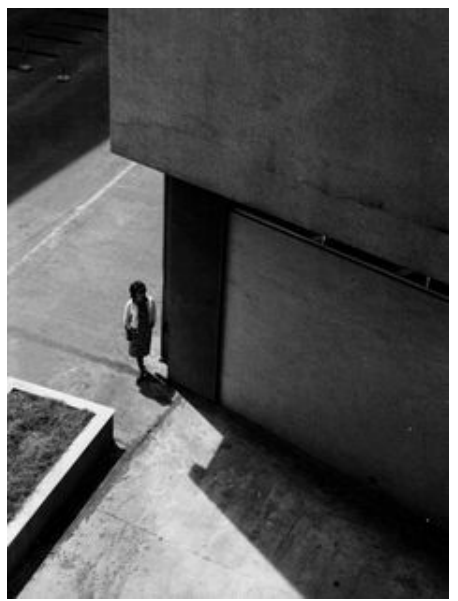

Disponível em: https://www.artsy.net/artwork/michelangelo-antonioni-la-notte-film-still-with-jeanne-moreau Acesso em: 25 abr. 2017

${ }^{25}$ Considerado isoladamente, esse fotograma poderia perfeitamente fazer parte de um filme que pertencesse à era do cinema clássico; se, ainda assim, o reproduzimos aqui é apenas como um convite ao leitor para rever essa tomada, no contexto da montagem que lhe dá sentido. 
Aceitando essa distinção entre dois tipos de imagem, tudo parece levar a crer que as imagens produzidas pelos drones pertenceriam ao primeiro grupo, o das imagens-movimento. Afinal, a detecção do deslocamento dos inimigos, sua perseguição pela câmera, o lançamento de mísseis, tudo isso parece remeter ao esquema sensório-motor que caracteriza essencialmente as imagens-movimento. ${ }^{26}$ Essa primeira aparência é, no entanto, enganadora; na verdade, o fluxo de imagens que chega a cada minuto aos centros operacionais dos drones é composto, em sua esmagadora maioria, por náo-eventos, por cenas em que nada se passa, em que nada passa, nada além do próprio tempo: longas horas de tocaia, muitas vezes sem nenhum resultado concreto. As cenas impactantes de bombardeios e mortes à distância são aquelas que os meios de comunicação de massa selecionam para produzir seus espetáculos sangrentos (parte, aliás, da estratégia de intimidação contra os inimigos), todavia, elas pouco têm a ver com as imagens cotidianamente, rotineiramente, burocraticamente observadas pelos operadores das máquinas, em tempo real, a milhares de quilômetros de distância.

O fluxo de imagens anônimas dos drones (mas também dos satélites e das câmeras de vigilância onipresentes nas grandes cidades) nos remete, portanto, às "situaçôes óticas puras", as quais são características da imagem-tempo; para descrevê-las usando as palavras de Deleuze (1990b, p. 13), podemos dizer que [...] tudo permanece real nesse neorrealismo [....], porém, entre a realidade do meio e a da ação, não é mais um prolongamento motor que se estabelece, é antes uma relação onírica, por intermédio dos órgãos dos sentidos, libertos. Dir-se-ia que a ação flutua na situação, mais do que a arremata ou encerra.

Federico Fellini, Luchino Visconti, David Lynch, todos eles criam suas imagens nesse ambiente onírico - e, nele, a própria história torna-se um pesadelo do qual não se consegue acordar, como dizia James Joyce -, o mesmo ambiente no qual, no contexto da vigilância permanente em que nos encontramos hoje, o olho-drone vaga, registrando o que sempre aparece como a iminência de uma ameaça raramente concretizada. É a raridade desse

\footnotetext{
${ }^{26}$ Seguindo de perto o Bergson de Matéria e memória, Deleuze assume como premissa que a imagem-movimento está sempre conectada à "inteligência" psicomotora. Ainda que uma ação não seja realizada atualmente em resposta a um estímulo externo provocado por imagens-movimento, ele se esboça virtualmente como tendências imperceptíveis em direção a açôes realizadas pelo corpo de quem as percebe. Já a "intuição" nos permite uma representação adequada da duraçáo, livre dos constrangimentos da necessidade de agir no mundo material. Ver, sobre esses pontos, BERGSON (1959, p. 171-179).
} 
encontro, aliás, que explica a alegria incontida dos jovens soldados, quando finalmente encontram uma situação de ataque. Nas páginas iniciais de seu livro já mencionado acima, $A$ Theory of the Drone, Chamayou reproduz uma série de diálogos reais entre operadores de drones militares norte-americanos e seus superiores $^{27}$; o que é transcrito a seguir, ocorreu entre soldados observando, na noite de 20 de fevereiro de 2010, imagens do Afeganistáo feitas por drones e retransmitidas em tempo real por satélites. Os soldados estão lotados na mais importante base de drones dos Estados Unidos, a Creech Air Force Base, no deserto do estado de Nevada. Como nota Chamayou (2015, p. 2),

[o] trabalho aqui é extremamente entediante. Os homens passam noites inteiras olhando uma tela na qual, durante a maior parte do tempo, aparecem imagens imutáveis de um outro deserto, no outro lado do mundo. Comendo Doritos e M\&Ms, eles esperam que algo aconteça.

Eis o diálogo:

01:05

SENSOR OPERATOR: That truck would make a beautiful target.

OK, that's a Chevy Suburban.

PILOT: Yeah.

SENSOR OPERATOR: Yeah.

...

01:07

MISSION INTELLIGENCE COORDINATOR: Screener said at least one child near SUV.

SENSOR OPERATOR: Bull [expletive] ... where?

SENSOR OPERATOR: Send me a [expletive] still, I don't

think they have kids out at this hour, I know they're

shady but come on.

SENSOR OPERATOR: Well, maybe a teenager but I haven't seen anything that looked that short, granted they're all grouped up here, but...

${ }^{27} \mathrm{Na}$ nota 3 do "Prelúdio" a seu livro, Chamayou informa: "Todos os diálogos citados são retirados de transcrições oficiais obtidas, graças ao Ato de Liberdade de Informação, por David S. Cloud, um jornalista do Los Angeles Times. São citados aqui somente extratos. O documento original foi censurado em várias passagens antes de ter sido tornado público." Para se ter acesso à íntegra do documento, ver: www.documents.latimes.com/transcript-of-drone-attack. Acesso em: 25 abr. 2011.

Para uma melhor compreensão do contexto em que esses documentos foram obtidos, Chamayou remete o leitor para o artigo de Cloud, Anatomy of an Afghan War Tragedy. Los Angeles Times, 10 abr. 2011. Na nota 2 do mesmo "Prelúdio", o autor remete também ao livro de Gerald Krueger e Peter Hancock, Hours of Boredom, Moments of Terror: Temporal Desynchrony in Military and Security Force Operations. Washington, DC: National Defense University, 2010. Cf. CHAMAYOU (2015, p. 229.) 
MISSION INTELLIGENCE COORDINATOR: They're reviewing . . . PILOT: Yeah, review that [expletive] ... why didn't he say possible child, why are they so quick to call [expletive] kids but not to call a [expletive] rifle? MISSION INTELLIGENCE COORDINATOR: Two children were at the rear of the SUV.

...

Nesse contexto, a maior violência não é necessariamente aquela que ocorre quando o gatilho é acionado e o inimigo é morto, mas sim esse tempo interminável da espera em que algo intolerável e insuportável - talvez náo para os soldados, contudo, ao menos para nós, ou para alguns de nós, que lemos seu diálogo - é apreendido em uma espécie de presente eterno, o tempo verbal pelo qual a eternidade do olhar de Deus sempre foi - ou tentou ser - expressa pelos teólogos e pelos filósofos. Ainda nas palavras de Deleuze (1990b, p. 29), e ainda sobre o cinema moderno (porém, poderia bem ser sobre os drones), nele se dá

[n]ão uma brutalidade como agressão nervosa, uma violência aumentada que sempre pode ser extraída das relaçóes sensório-motoras na imagem ação. Tampouco se trata de cenas de terror, embora haja, às vezes, cadáveres e sangue. Trata-se de algo poderoso demais, ou injusto demais, mas às vezes também belo demais, e que, portanto, excede nossas capacidades sensório-motoras.

O que é claramente evocado nessa passagem - "algo poderoso demais, ou injusto demais, mas às vezes também belo demais" - é o conceito de sublime, tal como ele é formulado na terceira Crítica de Kant. Não é demais lembrar que o sublime é, por excelência, o sentimento geralmente ligado à contemplação humana de Deus, ou seja, à visada temporal da eternidade. Recordemos também que, segundo Schmitt, o fim do poder transcendente do Estado moderno e o advento da identificação liberal entre o Estado e o conjunto imanente de suas leis nos colocam justamente na iminência da instauração de uma concepção da existência concentrada unicamente no presente eterno e no passado puro, sem abertura para o futuro. Examinemos um trecho bem conhecido de Schmitt (2014, p. 78-79):

Enquanto a história mundial não estiver encerrada, enquanto ela ainda estiver aberta e em movimento, enquanto as condiçóes ainda não estiverem para sempre fixadas e petrificadas, enquanto, em outras palavras, os seres humanos e os povos ainda tiverem um futuro, e não apenas um passado, um novo nomos surgirá nas formas fenomênicas sempre novas dos acontecimentos da história mundial. 
Se a história mundial já foi encerrada, então o presente eterno se manifesta através da impossibilidade de articular alternativas políticas para o futuro. $\mathrm{O}$ futuro, se houver um futuro, deve se enunciar no passado, como uma marcha a ré. Andreas Huyssen (2000) articulou claramente a experiência contemporânea do tempo presente. Segundo Huyssen (2000, p. 4),

[u]m dos fenômenos culturais e políticos dos mais surpreendentes dos últimos anos é a emergência da memória como uma das preocupaçóes culturais e políticas centrais das sociedades ocidentais. Tal fenômeno caracteriza um retorno ao passado que contrasta totalmente com o privilégio dado ao futuro, que caracterizou táo bem as primeiras décadas do século XX.

Huyssen (2000) dedica-se a avaliar esse fenômeno recente, estudando a arquitetura, os monumentos e os museus; ele também aplicou suas conclusóes sobre o estado da cultura contemporânea à disciplina da História e à proliferação "do discurso da memória no interior da própria historiografia." A velocidade das transformaçóes tecnológicas, diz-nos Huyssen, tem por efeito a produçáo de objetos que já nascem obsoletos; o presente, nessa cultura, se percebe como um ponto sem extensão, infinitamente concentrado. Mencionando as teorias do filósofo Hermann Lübbe ${ }^{28}$, Huyssen propóe que o olhar sobre o passado a partir desse presente contraído em um ponto instável produz uma "musealização" do mundo como forma compensatória - mas Huyssen não está de acordo com Lübbe, no que diz respeito ao sucesso dessa estratégia compensatória, na medida em que a "musealização" se perde ela mesma no tempo presente, expandindo-se em relação ao passado, em meio a novas imagens desestabilizantes produzidas incessantemente. Para o que nos interessa aqui, no atual contexto de nossas investigaçôes sobre os drones, para além desses fenômenos analisados por Huyssen, podemos recordar justamente o quanto a imagem-tempo deleuziana faz emergir o passado puro e um presente eterno.

Lembremos também que a Primeira Guerra Mundial representa, para Schmitt, o ponto de inflexão decisivo para o fim do poder soberano, concebido na forma tradicional do Estado moderno e do líder do povo capaz de decretar o estado de exceçấo. A ele sucede o poder total do Império americano (e/ou russo e/ou chinês), o estado de paz perpétua, ou seja, de guerra permanente, na qual o estrangeiro, o terrorista, é caracterizado como o inimigo de toda a humanidade,

${ }^{28}$ A obra por ele mencionada (p. 40, nota 16) é Zeit-Verhältnisse: Zur Kulturphilosophie des Fortschritts (Graz, Wien: Styria, 1983). 
considerada abstratamente como o operador político da eliminação da própria política. Ou ainda: ao se tornar imanente à sociedade dita democrática, o poder estatal torna-se poder totalitário. Nada escapa da política, ao mesmo tempo em que nada mais aparece como político. Nesse contexto, a imagem-tempo produzida pelos drones constitui a vida espiritual do Império.

\section{O ASPECTO TÁTIL DAS IMAGENS-TEMPO}

Mas as imagens dos drones têm uma propriedade suplementar que as singulariza frente a outros tipos de dispositivos óticos: sua dimensão tátil. Como foi advertido acima, não se trata de caracterizar esse aspecto tátil apenas pela junção da capacidade de atingir os inimigos, através de seu poder de fogo, à produção de imagens em tempo real, mas, antes, de encontrar, no interior mesmo das imagens, uma dimensão tátil. É verdade que os grafismos que acompanham as cenas capturadas pelos drones identificam imediatamente os objetos na tela como alvos para os mísseis, como podemos ver na captura de tela reproduzida abaixo (figura 7), feita por um drone americano no Iêmen:

Figura 7: What is ABI - and will it make drones even deadlier?

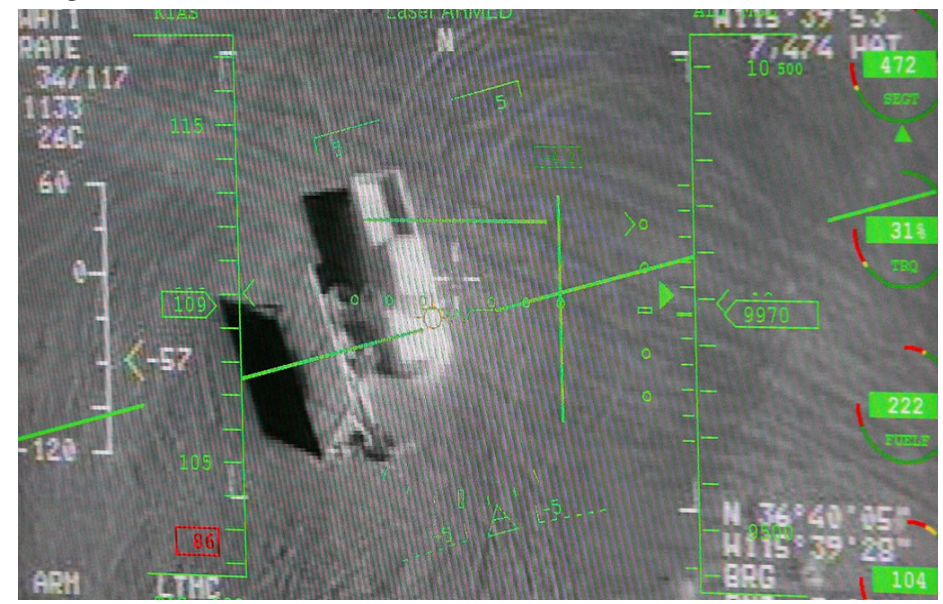

Disponível em: https:/www.channel4.com/news/drones-abi-activity-based-intelligence-yemen-strike-attack Acesso em: 06 maio 2017.

Esses grafismos, no entanto, também acompanham as imagens obtidas por avióes e satélites. A singularidade tátil dos drones reside, ao invés disso, em outro lugar, a saber, no fato de que o olho-drone obedece à distância, porém, instantaneamente, ao controle manual de seus operadores: ele pode se deslocar 
como um avião ou ficar imóvel como um helicóptero, pode subir ou descer, virar à esquerda ou à direita, voar mais ou menos rapidamente. Por ser um veículo não-tripulado, unmaned, como dizem os americanos (a expressão alternativa para designar os drones na língua inglesa é UAV, Unmaned Aerial Vehicle), todos esses movimentos dão às imagens um caráter tátil e encarnam a presença virtual da mão dos operadores no interior do que é retratado. Frisemos, a propósito, que, ao descrever as propriedades das imagens-tempo, Deleuze acrescenta, aos opsignos e sonsignos, os tatissignos, os quais, na verdade, seriam mais primitivos do que os dois primeiros: seriam os tatissignos que constituiriam os "espaços quaisquer" figurados pelo cinema moderno (por exemplo, o cinema de Werner Herzog), havendo, assim, "um tocar característico do olhar.", conforme palavras de Deleuze (1990b, p. 23). Ainda nas palavras de Deleuze (1990b, p. 22): “[...] é o tátil que é o mais apto a constituir uma imagem sensorial pura, com a condição de que a mão renuncie a suas funçóes preensíveis e motoras, contentando-se com um puro tocar."

Poder-se-ia objetar que os movimentos executados pelas mãos dos operadores dos drones, imediatamente visiveis no deslocamento das imagens, produziriam uma instância da imagem-movimento, mais do que da imagemtempo, pois a primeira, como vimos acima, seria aquela que se prolonga em esquemas sensório-motores, o que parece ser justamente o caso, quando se percebe a "presença" da mão do operador na variação dos movimentos e na velocidade de deslocamento das imagens obtidas por drones. A reação imediata mão-olho, tão típica dos jogos eletrônicos desde o Arcade da Atari, na década de 1970, e emulada cotidianamente pelos operadores dos drones, seria o exemplo mais acabado de tal conexão sensório-motora, na medida em que tal reação corporal, ao contrário da que ocorre no cinema, náo permaneceria no nível virtual, mas se manifestaria atualmente em movimentos concretamente exercidos. Como os "espectadores" das imagens produzidas pelos drones são, no mais das vezes, apenas os próprios operadores dos aparelhos e seus supervisores (porque as imagens que chegam às televisôes e à Internet são somente suas poucas açôes “espetaculares"), tal identidade entre o produtor dos movimentos e o espectador das imagens garantiria que estamos, de fato, lidando com representaçôes do tipo classificado por Deleuze como imagem-movimento.

Contra tal objeção, deve-se notar que a caracterização da imagem-drone como uma instância da espécie imagem-tempo se torna claramente defensável, desde que se tome a imagem-drone em si mesma, independentemente de quem atualmente, empiricamente, a vê. Todavia, o que significa "tomar a imagem- 
drone em si mesma"? Toda imagem não é, sempre, uma imagem para alguém, para um olho ou consciência que observa (isto é, que está diante (ob) de algo de que guarda ou cuida (servare))? E, para que uma imagem exista, ela não deve, além disso, ser atualmente observada por alguém? Uma imagem apenas potencialmente observável é ainda uma imagem ${ }^{29}$

A resposta para tais questôes pode ser procurada na obra de Bergson ${ }^{30}$, que é uma premissa central da teoria deleuziana do cinema, mas se encontra também em uma consideração sobre o estatuto dos signos na cultura contemporânea: há neles um excesso do que é representado que, paradoxalmente, barra a representação - pensemos no filme Empire, de Andy Warhol, ou nas 36 línguas do Finnegans Wake, de James Joyce. Nos dois casos - e em tantos outros, não só no domínio da arte, mas também nas câmeras de vigilância, nos satélites espióes etc. -, é impossível que tais obras tenham um espectador ou um leitor, não porque a imagem ou o texto sejam de alguma forma deficientes, nem porque lhes faltem, empiricamente, receptores, mas, ao contrário, devido a seu caráter absoluto: as imagens de Warhol, na sua máxima fidelidade ao "modelo", em seu excesso representativo, rompem com as ideias mesmas de representação e de visibilidade - ninguém, nem mesmo ele, nunca "viu" Empire. A imagem toma conta de todo o espaço da representaçáo, expulsando de sua vigência tanto o produtor (Warhol limitou-se a ligar a câmera e a deixála operando sozinha) quanto o (inexistente) espectador. Da mesma maneira, os fluxos das imagens-drone que formam o interminável arquivo de imagens do presente são analisados aqui do ponto de vista desse "espectador inexistente", da imagem em si mesma, a qual, como em um filme de $\mathrm{Ozu}$, resiste à visão do espectador. É do ponto de vista desse espectador virtual, portanto - mesmo que se trate, no caso, de um espectador (quase) inexistente - que a maior proximidade da imagem-drone com a imagem-tempo se manifesta.

Seria preciso desenvolver mais detalhadamente a questão da sinestesia presente na ideia de imagem-tátil. Como os limites deste texto não permitem fazê-lo, remeto os leitores ao estudo seminal de Jacques Derrida, intitulado Memórias de cego. $O$ autorretrato e outras ruinas, escrito originalmente

\footnotetext{
${ }^{29}$ Mesmo problema para George Berkeley, que deve dar conta da redução das "coisas" a "ideias" e, ao mesmo tempo, explicar como coisas nunca "observadas" por ninguém - uma pedra enterrada nas profundezas da Terra, por exemplo - podem, no entanto, ser ditas "existentes". Sua solução, como se sabe, é introduzir na teoria o conceito de mente de Deus, entendido como "observador universal".

${ }^{30}$ Bergson radicalizará a tese de Berkeley mencionada na nota anterior, ao propor, no início de Matéria e memória, que o próprio universo é constituído, em si mesmo, por imagens. Cf. BERGSON (1959, p. 170).
} 
como o texto da curadoria feita por Derrida para uma exposição realizada no Museu do Louvre, em Paris, em exibição nos anos de 1990 e 1991. Na impossibilidade de avançar mais na especificação do conceito de imagem tátil, limito-me a reproduzir uma das primeiras obras abordadas por Derrida, em seu livro, intitulada Cristo curando um cego, obra do gravador e pintor renascentista Lucas van Leyden (figura 8), na qual o caráter tátil da visualidade é evidenciado através da análise da representação das mãos das diversas personagens aí retratadas: ${ }^{31}$

Figura 8: Jésus guérissant un aveugle, de Lucas van Leyden

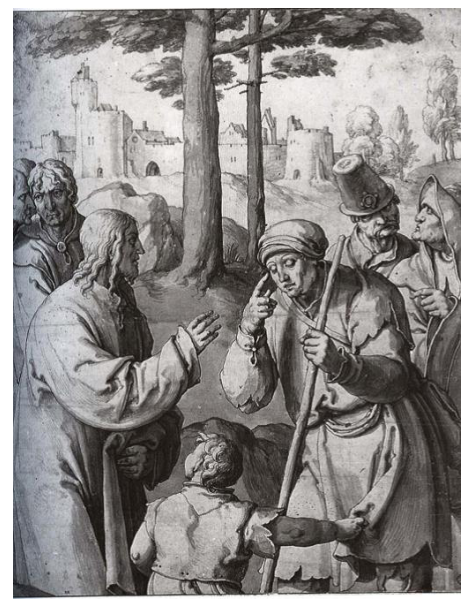

Fonte: Museu do Louvre

Poder-se-ia acrescentar à tese proposta acima sobre o caráter tátil das imagens produzidas pelos drones a observação sobre as sensaçóes geradas pelo movimento muscular do globo ocular, durante as mudanças de direção do olhar, tal como observou Berkeley (1948). Ao responder ao famoso "problema de Molyneux", Berkeley (1948) defendeu a heterogeneidade absoluta entre as percepçôes visuais e as táteis: apenas essas últimas nos dariam as ideias de exterioridade, de distância e, de forma mais geral, de espaço. No entanto, ele nos adverte também que o movimento dos músculos do globo ocular, e as sensaçóes hápticas próprias derivadas desses movimentos, associadas às sensaçôes visuais e sonoras, possibilitam-nos interpretar essas duas últimas como se elas também nos transmitissem informações espaciais. Ele consegue,

${ }^{31}$ Para a análise derridiana dessa imagem, cf. DERRIDA (2010, p. 18-20). 
assim, explicar como a formação do foco, no diagrama que vemos abaixo (figura 9), pode ser associada empiricamente à ideia de distância:

Figura 9: Formação do foco e determinação da localização dos objetos

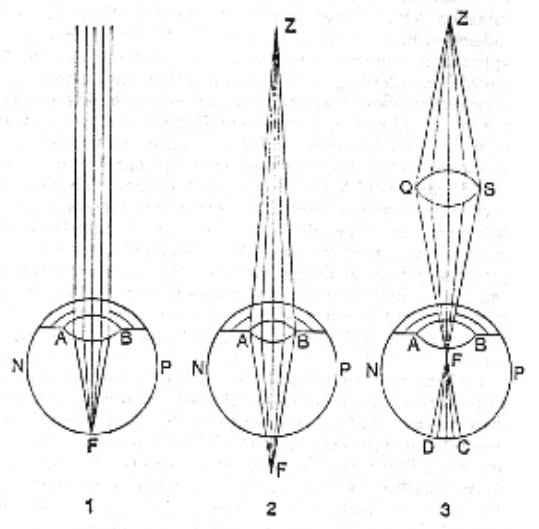

An Essay towards a New Theory of Vision, de Georges Berkeley, $₫$ XXXIV

Nesse sentido, o drone seria todo-olho e todo-músculo. Ora, é essa dimensão tátil, sinestésica, da imagem-tempo feita a partir dos drones que dá ao caráter aéreo do liberalismo político a sua completa imersão na imanência dos signos (signos tais como dinheiro, valores, afetos), caráter esse que caracteriza a teologia política contemporânea - não por acaso, Schmitt, cujas relaçóes problemáticas com o nazismo são bem conhecidas, afirma que tal imanência foi primeiramente proposta pelo "judeu e ateu” Spinoza e seu Deus imanente à Natureza. Mencionemos, a esse propósito, outra solução para o "problema de Molyneux", desta vez a de Denis Diderot. Em sua Carta sobre os cegos para uso dos que veem, Diderot começa seu texto narrando a história de um cego e a concepção peculiar que ele tem do espelho, objeto visual por excelência pois, ao olhá-lo, o que vemos é a própria visibilidade. Para o cego de Diderot, o espelho é como "uma máquina que coloca as coisas em relevo longe delas mesmas"32, quase como a sensação tátil transmitida pelos bastôes, na famosa ilustração da Dióptrica de Descartes (figura 10):

${ }^{32}$ No original, "une machine qui met les choses en relief loin d'elles-mêmes" (AT I, 281). 
Figura 10: Um cego tocando objetos com o auxílio de bastôes

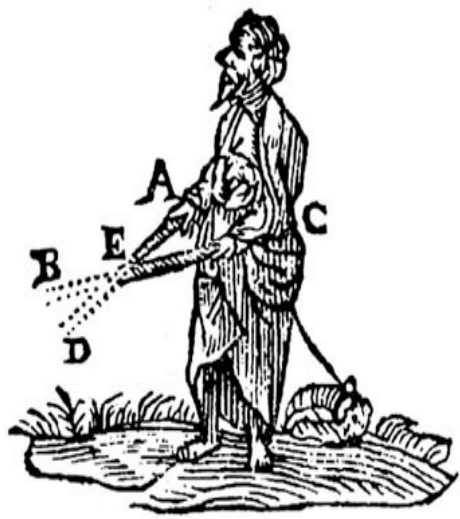

La Dioptrique, Discours VI, “De la vision”, de René Descartes

Essa "máquina tátil” pode nos guiar, sugere Diderot, embora através de caminhos obscuros, para fora do labirinto de espelhos onde se espera encontrar, em cada imagem, o mesmo, sempre reduplicado: se o espelho fosse tal como o cego o concebia, entâo, quando ele tocasse seu próprio rosto fora de si, seus dedos sentiriam a si mesmo como um outro. De maneira apenas aparentemente paradoxal, essa alteridade é obtida justamente pela imanência do objeto tátil e das máos que o tocam: os objetos, para o cego, inclusive se esse "objeto" for ele mesmo, não se distanciam de seu corpo como um fantasma duplicado e transcendente na imagem refletida em uma superfície lisa e distante de si: sujeito e objeto confundem-se indissociavelmente no tato, pois ambos se conjugam no espaço sem intervalo que une a pele ao que a afeta. É claro que nem tudo no cego de Diderot pode ser aplicado à imagem-tempo de Deleuze, a começar pela concepçấo sensório-motora que o primeiro traz à tona: o modelo tátil do conhecimento proposto por Diderot, por oposição ao modelo visual (que poderíamos chamar de platônico/cartesiano), caracteriza o sujeito cognoscente como alguém que, para tomar contato com os objetos, tem de agir no mundo, progredindo através de parcialidades nunca sintetizadas completamente pelo presente de uma imagem visual dada de forma contemplativa, mas apenas pela memória incessantemente reatualizada de toques passados. ${ }^{33}$

\footnotetext{
${ }^{33}$ A não ser, é claro, quando o objeto tátil for suficientemente pequeno para ser abarcado de uma só vez o que, de qualquer modo, não ocorre com a imagem - visual ou tátil - que uma pessoa tem de si mesma.
} 
Já a imagem-tempo de Deleuze, como vimos, está ligada à contemplação, mesmo quando (ou: sobretudo se) ela apresenta um caráter tátil. O ponto de contato aqui sugerido entre Diderot e Deleuze diz respeito apenas ao fato de que o tato introduz uma fissura ou fratura no interior do próprio sujeito, tornando-o distinto de si mesmo, na dispersão de seus objetos. Desse modo, não será mais possível identificar "a" posição do sujeito com uma das inúmeras perspectivas que ele poderia assumir - em um certo sentido, o próprio sujeito não poderia, desde então, conceber a si mesmo como sendo nada mais do que esse deslocamento de perspectivas parciais. Ou seja, sai de cena o sujeito simples e substancial do cartesianismo e aparece aquele que, desde então, nunca mais pôde se referir a si mesmo sem, simultaneamente, diferenciar-se de si por esse ato mesmo de reflexão - uma reflexão tátil, se pudermos nos expressar assim. Diderot pôde finalmente levantar as cortinas sobre o palco do teatro burguês, cuja tragicomédia ainda hoje encenamos.

A relação entre política e teatro já foi por demais estudada, primeiramente a partir da ideia mesma de representação. No texto intitulado "Diderot, Brecht, Eisenstein", Barthes (1990, p. 85) propóe uma indicação dessa correlação:

[...] a representação não se define diretamente pela imitação; se abandonarmos as noçôes de "real", de "verossímil”, de "cópia", haverá sempre "representação" enquanto alguém (autor, leitor, espectador) dirigir seu olhar para um horizonte e nele recortar a base de um triângulo de que seu olho (ou sua mente) será o vértice. O organon da Representação terá como duplo fundamento a soberania do recorte e a unidade daquele que recorta.

Nesse sentido preciso, não só o teatro e o cinema são as expressôes de uma "geometria do olhar": também a literatura clássica (isto é, legivel) é um discurso representativo, geométrico, parte das "artes dióptricas", para usar a expressão do próprio Barthes (1990). Conforme o "fundamento geométrico da representação", característico do teatro e do poder soberano (segundo Schmitt, em vias de destituição), a partir do qual, diz Barthes, "as coisas são sempre vistas de algum lugar", o recorte do quadro que mostra o espetáculo requer um "tema fetichista": "Esse lugar de origem é sempre a Lei: lei da sociedade, lei da luta, lei do sentido. A partir daí, toda arte militante só pode ser representativa, legal." O que Barthes (1990) quer dizer é que, por sua própria natureza, todo quadro apresenta um sentido a ser valorado: o recorte 
de uma cena só se justifica porque seleciona o que tem valor e o separa do sem-sentido.

Em contraste com essa concepção clássica de representação, talvez pudéssemos concluir que as imagens vindas dos drones sejam o retrato mais fiel desta nossa época imperial, depois do fim - mas o fim nunca acaba de chegar - do Estado soberano: não porque tais imagens reproduzam a realidade de um ponto de vista neutro, a partir de uma transcendência aérea e divina, todavia, justamente ao contrário, porque dissolvem a transcendência na imanência tátil de suas imagens e se perdem em um fluxo interminável de imagens-tempo puras. Não podemos nos esquecer, nesse mesmo contexto, de que é do ar e dos céus que a ameaça ecológica contemporânea provém com mais força, e também ela ligada a uma sensação tátil, a uma espécie de febre planetária crescente e suicida - e, na imanência do devir capitalista, o lema No future dos punks da década de 70 é alegremente adotado pelos assim denominados "agentes econômicos".

\section{Consideraçóes Finais}

O diagnóstico oferecido por Schmitt sobre a situação política contemporânea afirma, como vimos, que o progressivo desaparecimento do poder soberano tradicional transforma a natureza mesma do Estado, que passa a se identificar imanentemente com o conjunto das leis e com o corpo social - o que constitui, segundo ele, a própria definição de totalitarismo. Se aceitarmos esse diagnóstico, seria preciso redefinir a generalização crescente do "estado de exceção" nas sociedades políticas contemporâneas, identificada, entre outros, por Giorgio Agamben, pois a exceçáo não poderia mais ser entendida pelo exercício do poder soberano, mas, antes, a partir de seu fim. No entanto, a natureza do estado de exceçáo permanente em que vivemos, e no qual provavelmente passaremos cada dia mais a viver, talvez seja mais bem explicada pela convivência estratificada e simultânea de várias formaçôes políticas do que pela ideia schmittiana de sucessão - mais pela geologia do que pela história, em suma.

Para ilustrar essa possibilidade e, com ela, concluir, seria preciso ir ao Anti-Édipo, que Deleuze escreveu conjuntamente com Félix Guattari, pois aí encontraremos justamente essa concepção mais geográfica e geológica do que 
histórica da estrutura política. ${ }^{34}$ Segundo eles, a "máquina despótica bárbara” - isto é, em termos um tanto gerais, o Estado - vem parasitar as sociedades territoriais primitivas, conectando o povo, através do déspota, diretamente a Deus - lembremos a aliança entre povo, terra prometida e Deus do Deuteronômio, ou as análises do Estado teocrático hebreu da época de Moisés propostas por Spinoza, em seu Tratado teológico-político. Mas, de acordo com Deleuze e Guattari, tal parasitismo estatal não estabelece um corte absoluto com as antigas formas de territorialidade - ele as coloniza, ressignifica e submete. A desterritorialização promovida pela máquina despótica reelabora-se em uma reterritorialização que mantém sob si os mecanismos arcaicos de tomada e partilha da terra. A emergência da "máquina capitalista” no século XIX, ainda segundo Deleuze e Guattari, obedece à mesma lógica de desterritorialização e reterritorializaçáo, operando, sem destrui-los, sobre os códigos anteriores, inclusive (para o caso que nos interessa aqui) sobre o Estado, o qual passa então a, sem mais gozar de plena soberania, ser uma das engrenagens de tal máquina. Todavia, o capitalismo vai mais longe do que as formações políticas anteriores: ele promove uma desterritorializaçáo generalizada dos fluxos, ou seja, inaugura uma formação social que não se efetua mais pela codificação dos signos, mas sim pela operação formal - denominada por eles "axiomatização" - de controle dos fluxos decodificados. ${ }^{35}$

Seria preciso introduzir aqui toda uma discussão sobre esse novo aparato conceitual legado pelas obras de Deleuze e Guattari, especialmente em Capitalismo e esquizofrenia 1 e 2 e em Kafka. Por uma literatura menor. Porém, as limitaçôes de um artigo como este nos impedem de realizar tal tarefa neste momento e, simultaneamente, nos convidam a voltar a ela mais adiante, em outra ocasião. O que nos importa reter, por ora, é apenas a ideia de que o avanço da imanência do poder soberano ocorre paralelamente ao avanço do processo de desterritorialização política do capitalismo, sem que a passagem para um estágio mais avançado dessa trajetória tendencial signifique a pura e simples eliminação do estágio anterior: as formas transcendentes do Estado podem, assim, conviver com sua progressiva imanentizaçáo no corpo social.

\footnotetext{
${ }^{34}$ Para uma discussão metodológica sobre a substituição do modelo histórico pelo modelo geológico, cf. o começo do capítulo III de $O$ anti-Édipo, intitulado O socius inscritor (DELEUZE; GUATTARI, 1973, p. 163-170). Além disso, é importante consultar também outra obra escrita em conjunto pelos dois autores, Mil platôs, especialmente o capítulo intitulado "Geologia da moral" (DELEUZE; GUATTARI (1980, p. 53-94).

${ }^{35}$ Para uma análise da articulação dessas três formaçôes políticas, cf. PATTON (2000), especialmente seu Capítulo 5, intitulado "Social Machines and the State. The history and politics of deterritorialisation".
} 
Podemos, enfim, tendo em vista essa dimensão geográfica do poder, retomar e responder à questão que guiou a elaboração deste texto - a qual, justamente, relaciona a política à geografia, isto é, ao domínio da terra, do mar e do ar, seguindo a proposta de Schmitt. A questão foi assim formulada: há uma especificidade, uma qualidade intrínseca dos drones que os singularizaria diante de outros instrumentos técnicos de dominação aérea? A resposta sugerida acima é afirmativa: as imagens produzidas pelos drones, compreendidas a partir do conceito deleuziano de imagem-tempo e, especialmente, em função de sua dimensão tátil, correspondem exatamente ao processo de imanência progressiva do exercício do poder político, o qual, segundo Schmitt, caracteriza o liberalismo político. Assim, haveria não apenas uma diferença de graus entre, por um lado, os drones e, por outro, tecnologias mais tradicionais de controle aéreo, tais como satélites e avióes. Levando em conta algumas das propriedades das imagens produzidas pelos primeiros, vimos que seu caráter sinestésico impregna a visão de sensações táteis, fazendo a imagem visual tornar-se imanente à terra que representa. $\mathrm{O}$ Deus-transcendente desceu à terra e, sem se confundir com ela, nela passou a habitar: Deus-encarnado, ao mesmo tempo distante e próximo, Pai e Filho.

A "máquina-olho" chamada drone - que, como se sabe, significa, em inglês, o macho da abelha, o zangão, e, por metonímia, o ruído de seu zumbido $^{36}$ - seria, conforme essa concepção geológica do poder, um dos instrumentos contemporâneos da acima mencionada axiomatização, não na medida em que traça mapas e limites precisos para o território por ele observado (o que seria mais propriamente a função dos satélites), mas, ao invés disso, na medida em que o percorre incessantemente e, ao tocá-lo com seu olhar, se torna a ele imanente - recordemos que, no tato, o sentiente e o objeto sentido se encontram no mesmo plano. Se a exceção está em toda parte é porque o Estado soberano, no contexto imanentista do capitalismo tardio, se torna tấo mais totalitário, através de seus instrumentos burocráticos e tecnológicos, quanto mais aparentemente desaparece em seu interior. Como um cadáver insepulto, o Leviatã continuaria, ao contrário do que propóe Schmitt, mais vivo do que nunca, agora travestido, com seus cem olhos-drones, em outra forma igualmente monstruosa, a de Argos Panoptes.

36 Cf. o Online Etymology Dictionaire: "Old English dran, dræn 'male honeybee', from ProtoGermanic dran- (source also of Middle Dutch drane; Old High German treno; German Drohne, which is from Middle Low German drone), probably imitative; given a figurative sense of 'idler, lazy worker' (male bees make no honey) 1520s. Meaning 'pilotless aircraft' is from 1946”. Disponível em: www.etymonline.com/index.php?term=drone. Acesso em: 06 maio 2017. 
PINHEIRO, U. Drones, time-image and the end of sovereign power. Trans/form/açâo, Marília, v. 43, n. 1, p. 213-244, Jan./Mar., 2020.

\begin{abstract}
This paper deals with the specificity that characterizes one of the most important technological aerial products dedicated to surveillance and attack being in use nowadays, the drones, showing in which sense this new technology is a decisive turning point in the evolution of the domination of the skies and therefore, as suggested by Carl Schmitt, in the transformation of the political-theological field in contemporary societies. The radical immanence of the political field proposed by liberalism, such as Schmitt described it, finds in drones one of its most typical instruments. To characterize the specificity of drones regarding other visual and aerial war machines, it will be proposed an approximation with the Deleuzian concept of image-time, in order to determine its singularity through the intrinsic properties of the images so produced. The main characteristic of the Deleuzian time-image to be integrated in the analysis of drones will be its haptic aspect. At this point, the relation between Deleuze's cinema books and his work in collaboration with Félix Guattari will be essential to characterize the political dimension of the drone-image.
\end{abstract}

KeYwords: Drones. Cinema. War. Sovereignty.

\title{
REFERÊNCIAS
}

BARTHES, Roland. Diderot, Brecht, Eisenstein. In: BARTHES, Roland. O óbvio e o obtuso. Rio de Janeiro: Nova Fronteira, 1990. p. 85-92.

BERGSON, Henri. Matière e mémoire. In: BERGSON, Henri. Euvres complètes. Paris: Presses Universitaires de France, 1959. p. 161-382.

BERKELEY, George. An essay towards a New Theory of Vision. In: BERKELEY, George. The Works of George Berkeley. London: Nelson, 1948-57.

BOGUE, Ronald. Deleuze on Cinema. New York, London: Routledge, 2003.

BROOKES, Andrew. Art of the Redemption: Christ of St John of the Cross by Salvador Dali. The Dominican Friars, England, 17 maio 2011. Disponível em: http://english. op.org/godzdogz/art-of-the-redemption-4-christ-of-st-john-of-the-cross-by-salvador-dali. Acesso em: 07 abr. 2017.

CHAMAYOU, Grégoire. Théorie du drone Paris: La Fabrique Éditions, 2013.

CHAMAYOU, Grégoire. A Theory of the Drone. Tradução de Janet Lloyd. New York: The New Press, 2015.

DELEUZE, Gilles. L’image-mouvement. Paris: Les Éditions de Minuit, 1984.

DELEUZE, Gilles. L’image-temps. Paris: Les Éditions de Minuit, 1985. 
DELEUZE, Gilles. A imagem-movimento. Tradução de Stella Senra. São Paulo: Brasiliense, 1990a.

DELEUZE, Gilles. A imagem-tempo. Tradução de Eloisa de Araujo Ribeiro. São Paulo: Brasiliense, 1990b.

DELEUZE, Gilles; GUATTARI, Félix. Capitalisme et schizophrénie 1: L’anti-CEdipe. Paris: Les Éditions de Minuit, 1973.

DELEUZE, Gilles; GUATTARI, Félix. Capitalisme et schizophrénie 2: Mille plateaux. Paris: Les Éditions de Minuit, 1980.

DERRIDA, Jacques. Mémoires d'aveugle. L'autoportrait et autres ruines. Paris: Éditions de la Réunion des musées nationaux, 1990.

DERRIDA, Jacques. Memórias de cego. Lisboa: Calouste Gulbenkian, 2010.

DESCHARNES, Robert. Dali. New York: Harry N. Abrams, 2003.

FRANCO DE SÁ, Alexandre. O conceito de teologia politica no pensamento de Carl Schmitt e o decisionismo como ficção jurídica. Covilhã: LusoSofia, 2009.

HUYSSEN, Andreas. Present Pasts: Media, Politics, Amnesia. Public Culture, Nova York, v. 12 , n. 1, p. 21-38, 2000.

NOYS, Benjamin. Drone Metaphysics. Culture Machine, Mumbai, v. 16, p. 1-22, 2015.

Disponível em: www.culturemachine.net. Acesso em: 07 abr. 2017

PATTON, Paul. Deleuze and the Political. New York: Routledge, 2000.

SCHMITT, Carl. Political Theology II. The Myth of the Closure of Any Political Theology. Tradução de Michael Hoelzl e Graham Ward. Malden: Polity Press, 1970.

SCHMITT, Carl. Politische Theologie. Vier Kapitel zur Lehre von der Souveränität. Achte Auflage. Berlin: Duncker \& Humblot, 2004.

SCHMITT, Carl. O nomos da Terra no direito das gentes do jus publicum europæum. Tradução de Alexandre Franco de Sá [et al.]. Rio de Janeiro: Contraponto; Editora PUCRio, 2014.

VERTOV, Dziga. Articles, Journaux, Projets. Traduction et notes par Sylviane Mossé et Andrée Robel. Paris: Union générale d'éditions, 1972.

VIRILIO, P. Guerre et cinéma. Paris: Cahiers du Cinéma; Éditions de l'Étoile, 1984.

VIRILIO, P. War and Cinema: The Logistics of Perception. Trans. P. Camiller. London: Verso, 1989.

ZOURABICHVILI, François. The Eye of Montage: Dziga Vertov and Bergsonian Materialism. In: ZOURABICHVILI, François. The Brain is the Screen. Deleuze and the Philosophy of Cinema. Editado por Gregory Flaxman. Minneapolis, London: University of Minnesota Press, 2000. p. 141-152. 
PINHEIRO, U.

Recebido: 14/06/2017

Aceito: 29/11/2018 


\title{
COMENTÁRIo
}

\section{DRONES, IMAGEM-TEMPO E O FIM DO PODER SOBERANO: A aNOMALia do POLÍ́tico EM CARl SCHMitT}

\author{
Deyvison Rodrigues Lima ${ }^{38}$
}

Se fosse possível traçar um bestiário schmittiano, as figuras mais importantes seriam, sem dúvidas, o Leviathan e o Behemoth. É bem sabido que estas são metáforas utilizadas para se referir à luta entre potências marítimas e potências terrestres. Todavia, no livro Land und Meer (Terra e mar), surgem outras figuras do peculiar bestiário: a baleia - de modo literal, cuja caça fora responsável pela expansão das navegaçóes - e um pássaro, que insere outro elemento não apenas na zoologia, mas também na bárbara geopolítica de Schmitt, pois

[...] irrompe um terceiro elemento, o ar [die Luft] como novo âmbito elementar da existência humana. Aos animais míticos Leviathan e Behemoth, viria a somar-se um terceiro, um grande pássaro [...] se se pensa nos meios e energias técnico-mecânicas com que o homem exerceu seu senhorio no espaço aéreo [Luftraum], parece ser o fogo o novo elemento em que tem irrompido" (SCHMITT, 2001, p. 105, grifos do autor).

No entanto, apesar de pressentir o niilismo insuportável do racionalismo moderno, Schmitt (2001, p. 107) sustenta que "[...] aquilo que vem [das Kommende] não é, porém, uma falta de medida [Maßlosigkeit] ou hostilidade niilista ao nomos [nomosfeindliches Nichts] [pois] mesmo na luta mais encarniçada das forças novas e antigas, surgem medidas adequadas

\footnotetext{
${ }^{38}$ Professor no Departamento de Filosofia da Universidade Federal do Piauí (UFPI). (D) https://orcid. org/0000-0002-7879-8388. Email: deyvisonrodrigues@yahoo.com.br
}

http://dx.doi.org/10.1590/0101-3173.2020.v43n1.13.p245 
[gerechte Maße] e proporções razoáveis são formadas." Nesse caso, o niilismo se traduz como ausência de espaço, isto é, a ausência de nomos. O termo nomos significa, a rigor, a plena "imediatidade de uma força jurídica não mediada por leis [Unmittelbarkeit einer nicht durch Gesetze vermittelten Rechtskraft]", ou, ainda, "[...] um acontecimento histórico constitutivo [ein konstituierendes geschichtliches Ereignis]" (SCHMITT, 1997, p. 42), que articula Ortung e Ordnung como medida contra a desterritorialização (Entlandung), a desorientação (Entortung) ou a dissolução (Auflösung) do próprio espaço, sobretudo a partir das mudanças ocorridas no século XX: enquanto as guerras de ocupação (terra) ou de bloqueio (mar), entre Behemoth e Leviathan, ainda preservavam uma reordenação e um novo nomos, a guerra aérea se caracterizaria como a própria destruição do espaço. Eis o perigo que Schmitt antecipa, afinal, quando desenvolve sua obsessão e sustenta que "onde há espaço, há ser [Wo Raum ist, ist Sein]" (SCHMITT, 1991, p. 317). Nessa abertura entre espaço e política, movem-se os argumentos deste comentário.

O texto de Pinheiro parte da premissa schmittiana da transposição semântica em relação à instauração de campos ou instâncias, empregando como paradigma a relação entre teologia e política. Nessa relação, haveria uma assimetria das instâncias em jogo, com primazia do teológico, do qual o político seria uma mediação. Após a exposição da premissa, o argumento principal surge, qual seja, de que haveria uma nova instauração do campo político marcada, dessa vez, pela tecnologia, mais precisamente, pelo domínio dos céus. Todavia, ao contrário da teologia política, desenvolve-se uma perspectiva mais literal da relação entre céu e terra, através dos dispositivos tecnológico-militares dos drones. Estes assumiriam a posição de olho de Deus e, por conseguinte, os atributos e suas implicaçóes políticas. Perspicazmente, Pinheiro (p. depois averiguar) sustenta que a "[...] era dos drones representa de fato uma nova realidade política, ou, pelo menos, realiza a completude da metamorfose em curso desde o fim do nomos da Terra europeu”. Após a referência aos drones como prótese do poder soberano, o autor analisa os signos visuais produzidos, utilizando-se da obra de Gilles Deleuze, sobretudo a distinção entre imagem-movimento e imagem-tempo, e estabelece o ponto fundamental do debate: os drones - e as imagens elaboradas - como um objeto metafísico, a nova figura maquínica do atroz bestiário.

Nesse contexto, numa formulação sofisticada, Pinheiro (p. depois averiguar) argumenta que "[...] a imagem-tempo produzida pelos drones constitui a vida espiritual do império." Ora, tal afirmação reverbera um trecho 
bastante conhecido da Politische Theologie, na qual é ressaltada a articulação entre imanência e transcendência: "imagem metafísica que se faz uma determinada era do mundo tem a mesma estrutura [...] como forma da sua organização política” (SCHMITT, 2004, 50-51) ou, então, de que “[...] a metafísica é a mais clara e intensa expressão de uma época." (SCHMITT, 2004, p. 51). Tal leitura é, ainda, mais evidente quando assume as passagens de um "âmbito central [Zentralgebiet]" (SCHMITT, 1996, p. 81) para outro, sucessivamente, entre teologia, metafísica, moral, economia e, por fim, a técnica como a procura de um âmbito neutro para a racionalidade ocidental. No entanto, nessa busca obsediada, a conjuração do espectro faz com que aquilo que é exorcizado retorne, qual seja, a contingência e o conflito como a Gefärhlichkeit ineliminável da condição humana, uma vez que "[...] o político é não objetivo [unsachlich]." (SCHMITT, 2008, 27).

Dessa maneira, é importante a constatação schmittiana de que "[...] nenhum sistema político pode sobreviver, mesmo por uma geração, através da mera técnica de manutenção do poder." (SCHMITT, 2008, p. 28). Em outros termos, o teorema da secularização evidencia a incapacidade do racionalismo moderno em providenciar uma forma política à realidade, visto que tanto a economia quanto a técnica almejam uma presença imanente do mundo (FERREIRA, 2004). Entre a autoridade da decisão suprema (soberania) e a máquina administrativa estatal (governo), cresce uma racionalização burocrática na qual a soberania perde espaço diante dos procedimentos técnicos e impessoais da atividade governamental, resultando na impossibilidade de fundamentação da ordem política, já que, no liberalismo, a imagem central da modernidade é a de um mundo autogovernado pelo funcionamento das leis naturais imanentes, isto é, a imunização do conflito e a segurança e certeza na ordem jurídico-política. Entretanto, o dado mais característico dessa metafísica da imanência seria o controle pretensamente neutro e técnico por meio da lógica autônoma de uma "legalidade [Gesetzmäßigkeit] imanente" (SCHMITT, 2008, p. 60), revelando-se uma hiperpolitização imediatista e fanática. Assim, essa nova formação social, o Estado sob a máquina do liberalismo (mas também do capitalismo), torna a exceção onipresente (sem o lastro estruturante da relação entre teologia e política) e, por isso, totalitário, sobretudo em seus dispositivos mais recentes.

Seja por sustentar que o Estado moderno (e a categoria de soberania) entra em decadência com a identificação imanente entre o Estado e suas leis, seja ao perceber que o fim do poder soberano transforma o poder estatal 
em poder totalitário (sobretudo com as próteses-drones e a dissolução da bipolaridade imanência-transcendência), um problema nos assedia, qual seja, há algo que escape da imanência da racionalidade moderna? Em contraposição à absoluta imanência, o jurista move sua máquina e bestiário numa genealogia da desconstrução da política, ao lançar luzes em direção à origem inconfessável da ordem. Nesse sentido, desde o mecanismo da decisão soberana, da relação de conflito entre amigo e inimigo ou ainda através da apropriação originária da terra/espaço, Schmitt (2004) propóe a exceção, o político ou o nomos como modos disruptivos contra o sistema de normas imanente. O argumento da exceção como negatividade irreconciliável, por exemplo, expóese como fundamento irracional da ordem. Isso porque, segundo Schmitt (2004, p. 37-38), "[...] do ponto de vista normativo, a decisão surge do nada”, irrecuperável em termos dialéticos. Desse modo, Schmitt ressignifica o sentido da transcendência, ao pensá-la não como transcendência para além da imanência, mas sim como transcendência na imanência (cf. OJAKANGAS, 2005). Assim, a perda da transcendência como característica da modernidade implica uma realocação desta (e do princípio irracional que ela traz consigo) na própria imanência, caracterizando uma abertura na nervura imanente do real. Em suma, aquilo que institucionaliza a ordem é ininstitucionalizável, exterior aos cálculos e procedimentos. Uma instância de contingência como momento de transcendência, isto é, de abertura na imanência do mundo que, porém, é constitutivo da própria ordem, mesmo que seja ex-posição da ordem e retraição dos esquemas racionalistas.

Nesse momento, surge uma inesperada aliança entre Schmitt e Espinosa acerca da potência constituinte como dispositivo disruptivo-constitutivo, da diferença irredutível como conflito ininstitucionalizável ou ato originário (NEGRI, 2002). Ao pressagiar a falência do mecanismo estatal - de fato, encontramo-nos no limiar do jus publicum Europaeum e de suas consequências niilistas - Schmitt conserva uma linha de resistência que demonstra o cerne da questão do político: "[...] o turbilhão do vazio, do abismo da ausência de determinaçóes, como uma necessidade aberta.” (NEGRI, 2002, p. 26). Propóe-se, por meio de uma genealogia herética - de Nietzsche a Espinosa, a anomalia do político contra a transcendência da ordem. Afinal, não seria outra a postura do realismo político schmittiano. ${ }^{39}$ A tentativa de Schmitt,

\footnotetext{
${ }^{39}$ Mesmo na teologia política schmittiana, transcendência não se refere a um deslocamento a-histórico em busca de uma fundamentação universalista. Ferreira (2004, p. 36), mais uma vez, é lúcido quando afirma que "[...] a presentificação política, até certo ponto, remete a si mesma e não a um referente externo. Ainda que implique uma dimensão transcendente, esta não está dada fora da representação,
} 
ao romper com a imanência (totalitária) do racionalismo e do sequestro liberal da forma-estado implica o político - ou o poder constituinte - como o dispositivo ontológico da "[...] impossibilidade de conter a potência natural na ilusória racionalidade." (CASTRUCCI, 1999, p. 246). Em outras palavras, o irredutível dispositivo ontológico dos antagonismos e das forças como o único modo de escapar - caso Pinheiro tenha razão - do Argos Panoptes. A saída, por mais bárbara que pareça, seria atravessar o niilismo da metafísica, aquilo que Schmitt nos apresenta como herança e dívida.

\section{REFERÊNCIAS}

CASTRUCCI, Emanuele. Genealogie della Potenza Costituente. Schmitt, Nietzsche, Spinoza. Filosofia Politica, Minas Gerais, n. 2, p. 245-251, ago. 1999.

FERREIRA, Bernardo. Schmitt, representação e forma política. Lua Nova, São Paulo, n. 61, p. 25-51, 2004.

NEGRI, Antonio. O poder constituinte: Ensaios sobre as alternativas da modernidade. Tradução de Adriano Pilatti. Rio de Janeiro: DP\&A, 2002.

OJAKANGAS, Mika. Philosophies of "Concrete" Life: From Carl Schmitt to Jean-Luc Nancy. Telos, Spain, v. 132, p. 25-45, 2005.

SCHMITT, Carl. Das Zeitalter der Neutralisierungen und Entpolitisierungen. In:

SCHMITT, Carl. Der Begriff des Politischen. 6. ed. Berlim: Duncker \& Humblot, 1996.

SCHMITT, Carl. Der Nomos der Erde. 4. ed. Berlim: Duncker \& Humblot, 1997.

SCHMITT, Carl. Glossarium. Aufzeichnungen der Jahre 1947-1951. Eberhard Freiherr von Medem (org). Berlim: Duncker \& Humblot, 1991.

SCHMITT, Carl. Land und Meer. 4. ed. Stuttgart: Klett-Cotta, 2001.

SCHMITT, Carl. Politische Theologie. Vier Kapitel zur Lehre von der Souveränität. 8. ed. Berlim: Duncker \& Humblot, 2004.

SCHMITT, Carl. Römischer Katholizismus und politische Form. 5. ed. Stuttgart: KlettCotta, 2008.

mas é pressuposta e, em última análise, 'posta' por ela, distinguindo-se, assim, da natureza substancial da transcendência divina." 
LIMA, D. R. 


\title{
COMENTÁrios
}

\section{DRONES, IMAGEM-TEMPO E O FIM DO PODER SOBERANO: DRONES E A GEOPOLÍTICA CONTEMPORÂNEA}

\author{
Leonardo Monteiro Crespo de Almeida ${ }^{40}$
}

O artigo de Ulysses Pinheiro dá continuidade ao tipo de experimentação filosófica que já se mostrara, de maneira célebre, no projeto em comum de Gilles Deleuze e Félix Guattari, Capitalismo e Esquizofrenia: estabelece relaçóes inusitadas, desloca autores para contextos que lhes eram estranhos, revisita campos estabelecidos para propor novas questôes, tal como fizeram os dois autores, há algumas décadas. Sua análise dos drones concebidos através de um panorama político preconizado por Carl Schmitt situa-se próxima dos diagnósticos referentes às novas tecnologias realizados por Paul Virilio, cujo conhecido trabalho sobre a guerra e a maneira como as novas tecnologias instauram uma nova percepção sobre o conflito é também citado pelo autor.

Tendo em vista que a tecnologia dos drones introduz consigo uma série de diferenças consideráveis perante as representaçóes usuais dos conflitos bélicos - a guerra dita tradicional ou até mesmo de guerrilha -, assim como também as tecnologias de segurança até então empregadas, uma política dos drones pede a sua própria metafísica, tal como Henri Bergson falara da ciência de sua época. Ainda que as tecnologias de controle dos espaços aéreos, a exemplo de satélites, há muito já estejam assentadas, os drones não impóem apenas uma diferença em termos de graus, modificando também a maneira como se pode discutir e investigar a soberania na teoria e filosofia política contemporâneas. Que a soberania é um conceito no qual a territorialidade fora

${ }^{40}$ Professor na Faculdade Imaculada Conceição do Recife. (D) https://orcid.org/0000-0001-57423344. E-mail: leonardoalmeida326@gmail.com

http://dx.doi.org/10.1590/0101-3173.2020.v43n1.14.p251

This is an open-access article distributed under the terms of the Creative Commons Attribution License. 
sempre uma constante, isso não é novo, mas também não é novo - e o autor precisamente assinala essa hipótese - que o desenvolvimento do capitalismo ocorre em meio à sua progressiva desterritorialização.

É por meio de uma análise dessa nova tecnologia que o autor associa a desterritorializaçáo econômica do capitalismo com uma soberania política que, aos poucos, tende a se desarticular da sua fixação espacial. Nesse processo, a imanência política que fora apontada por Schmitt adquire um novo sentido, inclusive bélico e estratégico, instaurando, também, uma modificação na maneira de situar a soberania e a temporalidade. Uma guerra de drones é uma guerra travada sobre uma concepção de temporalidade que, ao menos até a Guerra do Golfo, fora estranha, mas que daquele conflito se torna cada vez mais presente, com a consequente espetacularização apontada por Virilio, em obras como Desert Screen e na citada War and Cinema.

Se, em Desert Screen, uma obra que vê na Guerra do Golfo um divisor de águas, Virilio já havia alertado para a forma como as novas tecnologias podem minar as atividades diplomáticas e os esforços envolvidos nas negociaçôes, os drones consolidam de vez essa hipótese. Diante de uma vigilância constante e de um olhar onipresente, a diplomacia se converte em uma atividade de dissimulação e narrativa que, em sua teatralidade, remete a uma lógica e discurso político extemporâneo. Existe pouca relevância para o diálogo, quando uma tecnologia permite concretizar objetivos de vigilância e destruição à distância, possibilitando, inclusive, o anonimato dos autores das ordens. É claro que esse contínuo deslocamento provocado por esse olhar distinto, que fora trazido pelos drones, não elimina as noçóes conceituais que servem para representar, e daí também intervir, nos diversos panoramas políticos, como a ideia de soberania política e, mais recentemente no campo da teoria política, o Estado de Exceção.

Ulysses Pinheiro dedica algumas páginas a discutir também o terceiro aspecto do ritornelo estabelecido por Deleuze e Guattari, em Mil Platôs, a saber, a reterritorialização. Os drones não eliminam essas noçóes, antes as inserem em um conjunto diverso de relaçóes conceituais que, por sua vez, transformam a composição e a consistência interna dos seus elementos usuais. Dito de outro modo, se permanece sendo pertinente falar em estado de exceção na geopolítica contemporânea, considerando já de início o presente aparato tecnológico, assim ocorre porque a reinserção desse conceito é realizada a partir da colocação de problemas novos e questóes distintas que emergem nesse panorama político. 
Um dos pontos suscitados pelo artigo aqui comentado, que entendo como muito produtivo, reside, então, na ponte entre o estado de exceção, o Estado de Direito (Rule of Law) e a tecnologia dos drones. Não se trata apenas de afirmar que, nas democracias contemporâneas, a exceção tem se tornado cada vez mais contínua e persistente, tal como Agamben já o fizera: enquanto tecnologias de vigilância e monitoramento, os drones trazem consigo um amplo repertório de atividades e intervençôes que se desenvolvem, inclusive, em paralelo à aplicaçáo regular das disposiçóes normativas do direito.

Se o invólucro normativo do Estado de Direito, em tese, proporcionaria ao cidadáo, antes de mais nada, uma proteção contra a intervenção indevida do Estado ou de um terceiro, os drones introduzem uma forma de intervenção fantasmática, na qual a intervenção efetivamente existe, mas a responsabilização é elusiva, senão inviável. A operação dos drones é impessoal e distante: o pressionar de um botão implica a destruição de pessoas e vilarejos distantes, tão despersonalizados quanto as vítimas dos antigos genocídios, senão ainda mais. O contato humano é substituído por imagens elusivas que prontamente desaparecem, uma vez realizada a atividade.

Nisso também se abre um espaço para outra investigação que perpassa as sucessivas transformaçóes pelas quais passou o conceito de Estado, ao longo do século vinte, e tentar pensá-las ao lado do que $S$ chmitt concebe não apenas nos dois volumes de sua Teologia Política, como no bem citado Nomos da Terra. Uma análise dessas transformaçóes permitiria redefinir a relevância - ou não - de noçôes como soberania, inclusive para os atuais debates referentes à biopolítica e às novas tecnologias de combate e monitoramento, como os drones. Ao menos, duas consideraçóes podem ser feitas a partir desse ponto.

A primeira delas estaria expressa no seguinte questionamento: ainda existiria algum resquício de centralização do poder, seja ele localizado e difundido pelo Estado-nação, seja por algum organismo supranacional? Se afirmativo, como concebê-lo através de um cenário no qual as fronteiras que outrora atuavam como delimitação territorial da soberania perdem mais e mais o seu sentido e observação? O cerne dessa primeira consideração é a relação entre soberania, território e tecnologia.

A segunda consideração recai sobre a necessidade de se reconsiderar a relação entre norma e exceção, quando o ponto fixo da soberania estatal se torna cada vez mais volátil, principalmente quando pensada em função das difusas e elusivas operaçóes do capitalismo globalizado, das diversas formas 
de monitoramento presentes nas relaçóes internacionais, da assimilação e comercialização de informaçóes particulares (Big Data) pelos conglomerados empresariais, dentre outros. Trata-se de um ponto que se localiza na interseção entre teoria do direito e teoria política: como desenvolver analiticamente a distinção entre norma e exceção, em meio à dinâmica dos ordenamentos jurídicos contemporâneos, quando o emprego de tecnologias de monitoramento paulatinamente corrói, por vezes em prol de um suposto "bem maior" ou "coletivo", os valores fundamentais daquele mesmo ordenamento?

Se os conceitos desenvolvidos pelas diversas filosofias e formas de teoria trazem consigo problemas e questóes desenvolvidas a partir de planos muito específicos e sempre mutáveis, artigos como esse permitem realizar esse exercício necessário de redefinição e sem o qual a teoria perde a sua relevância. Tomando os drones como seu ponto de partida e eixo central de investigaçáo, Pinheiro pensa a reterritorialização mesma da política contemporânea, em seus múltiplos devires rumo a algo que desconhecemos e que, por isso mesmo, permanece animando a nossa criatividade teórica. 